\section{LIBRARY}

U. S. BUREAU OF MINES

Western Field Operation Cenier East 360 3id Ave

Sp kene, Washingion 99202
BUREAU OR MINES

LIBRARY

SPOKANE, MASH

JUL 231985

RLLASE RETUR.

RO HBRARY

\title{
Relationships Between Geology and Engineering Characteristics of Soils and Weathered Rocks of Fairfax County and Vicinity, Virginia
}

U.S. GEOLOGICAL SURVEY PROFESSIONAL PAPER 1344

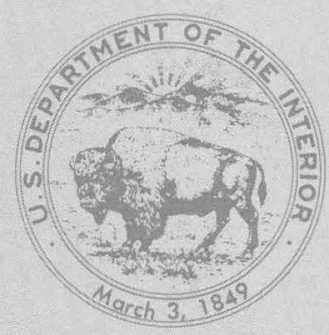




\section{Relationships Between Geology and Engineering Characteristics of Soils and Weathered Rocks of Fairfax County and Vicinity, Virginia}

By STEPHEN F. OBERMEIER and WILLIAM H. LANGER

U.S. GEOLOGICAL SURVEY PROFESIONAL PAPER 1344

UNITED STATES GOVERNMENT PRINTING OFFICE, WASHINGTON : 1986 


\section{UNITED STATES DEPARTMENT OF THE INTERIOR}

DONALD PAUL HODEL, Secretary

\section{GEOLOGICAL SURVEY}

Dallas L. Peck, Director

Library of Congress Cataloging in Publication Data

Obermeier, Stephen F.

Relationships between geology and engineering characteristics of soils and weathered rocks of Fairfax County and vicinity, Virginia

(U.S. Geological Survey professional paper ; 1344)

Bibliography: p.

Supt. of Docs. no.: I 19.16:1344

1. Engineering geology-Virginia-Fairfax County. 2. Weathering-Virginia-Fairfax County. 3. Rocks.

I. Langer, William H. II. Title. III. Series: Geological Survey professional

paper ; 1344.

$\begin{array}{llll}\text { TA705.3.V8034 } & 1985 & 624.1^{\prime} 51^{\prime} 09755291 & 84-21209\end{array}$

For sale by the Branch of Distribution

Books and Open-File Reports Section

U.S. Geological Survey

Federal Center

Box 25425

Denver, CO 80225 


\section{CONTENTS}

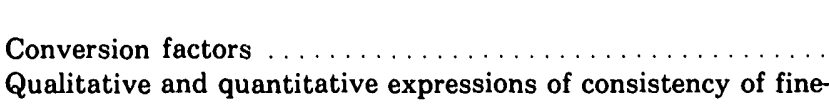
grained soils and compactness of coarse-grained soils ..... IV

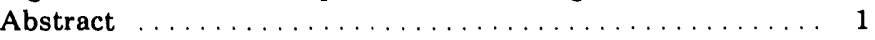

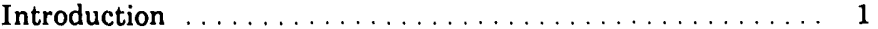

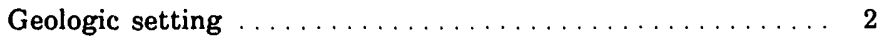

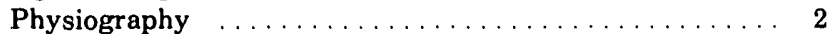

Geologic history and processes . . . . . . . . . . 3

Overview of characteristics of and processes involving geologic materials

Nonconsolidated materials ..................

Sedimentary rocks and their weathering products ..... 5

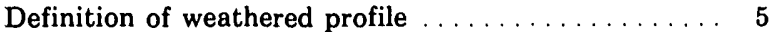
Lithologic control of weathered profile . . . . . . . 6 Joints, fractures, and parting planes . . . . . . . 8

Crystalline rocks and their weathering products ...... 9 Definition of weathered profile $\ldots \ldots \ldots \ldots \ldots \ldots$ Lithologic control of weathered profile . . . . . . . 10 Joints, parting planes, and foliation shear zones . . . 11 Lateral variations in weathering ............13
Tables of physical properties and engineering character-

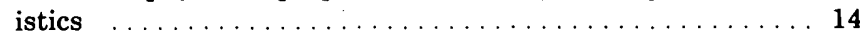

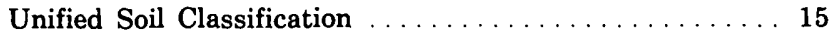

Total unit weight $\ldots \ldots \ldots \ldots \ldots \ldots \ldots \ldots \ldots \ldots$

Drainage and natural-moisture characteristics . . . . . 15

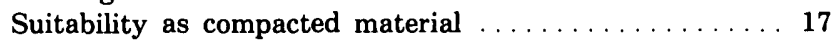

Excavation properties $\ldots \ldots \ldots \ldots \ldots \ldots \ldots$

Susceptibility to erosion $\ldots \ldots \ldots \ldots \ldots \ldots \ldots$

Shear strength and compressibility characteristics . . . . 19

Strength and characteristics of units ........ 19

Compressibility test methods and characteristics of

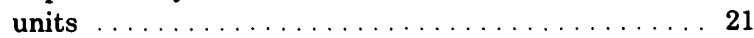

Allowable bearing pressure $\ldots \ldots \ldots \ldots \ldots \ldots \ldots$

Slope stability $\ldots \ldots \ldots \ldots \ldots \ldots \ldots \ldots \ldots \ldots \ldots$

Road-performance characteristics ............27

Seismic-refraction-velocity data and interpretations . . . . . 28

Digging of materials $\ldots \ldots \ldots \ldots \ldots \ldots \ldots \ldots$

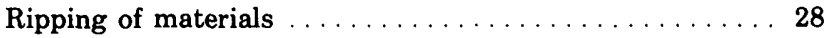

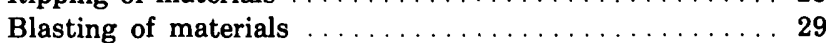

Selected references $\ldots \ldots \ldots \ldots \ldots \ldots \ldots$

\section{ILLUSTRATIONS}

PlATE 1. Surface materials map of Fairfax County and vicinity

[In pocket]

Figure 1. Index and geologic sketch map showing Fairfax County and vicinity

2. Diagrammatic cross sections showing relationships between nonconsolidated surface materials and underlying materials

3. Photographs showing Potomac Formation sand, silt, and clay overlain by the upland gravel unit ............ 6

4. Photograph showing colluvium overlying saprolite formed from phyllite $\ldots \ldots \ldots \ldots$

5. Diagram showing weathered profile on sedimentary rocks $\ldots \ldots \ldots \ldots$

6. Photograph showing fractures in residuum and weathered rock on siltstone $\ldots \ldots \ldots$

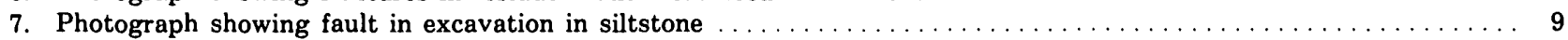

8. Diagram of typical weathered profile on crystalline rocks $\ldots \ldots \ldots \ldots \ldots$

9-13. Photographs showing:

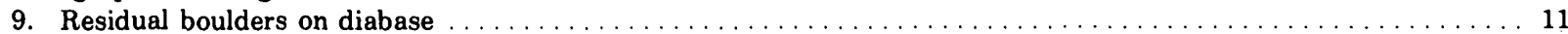

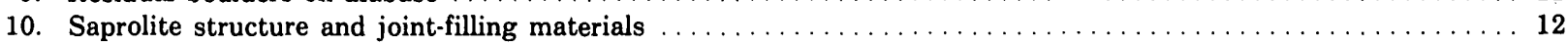

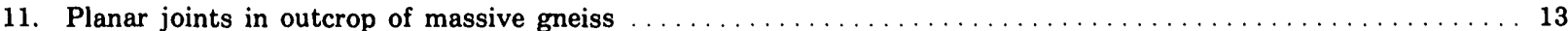

12. Joints and other partings in metamorphosed, folded, unweathered metagraywacke $\ldots \ldots \ldots \ldots$

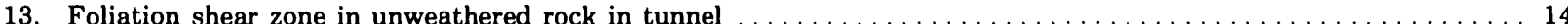

14. Diagram of idealized weathered and permeability profile $\ldots \ldots \ldots \ldots$

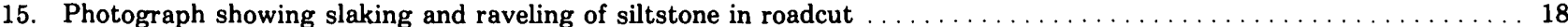

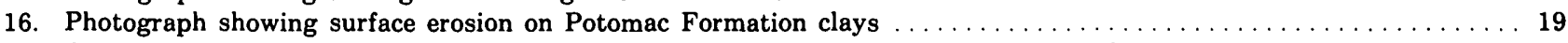

17. Diagrams showing strength relationships for drained direct-shear tests on Potomac Formation soils ........... 20

18. Diagram showing relation of foundation pressure on saprolite or residuum to Standard Penetration Test blow-count data 22

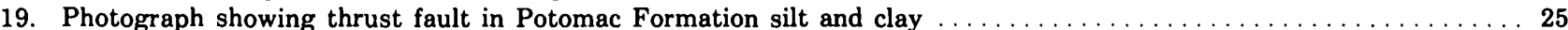

20. Diagram showing critical zones of weakness in slopes on the Potomac Formation $\ldots \ldots \ldots \ldots$

21-24. Photographs showing:

21. Zone of closely spaced subhorizontal partings through Potomac Formation clay $\ldots \ldots \ldots$

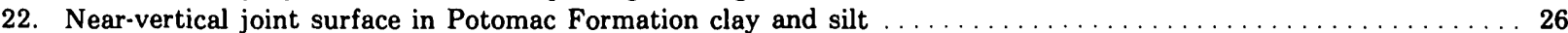

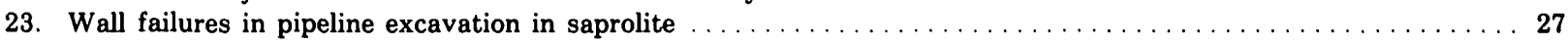

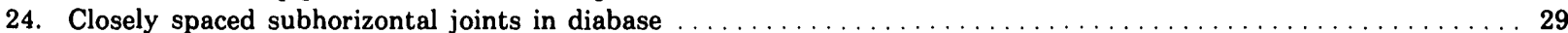




\section{TABLES}

[Tables 1-4 in pocket]

TABLE 1. Physical properties and engineering characteristics of nonconsolidated materials.

2. Physical properties and engineering characteristics of weathered materials on sedimentary bedrock.

3. Physical properties and engineering characteristics of weathered materials derived from metamorphic rocks.

4. Physical properties and engineering characteristics of weathered materials derived from igneous or slightly metamorphosed igneous rocks.

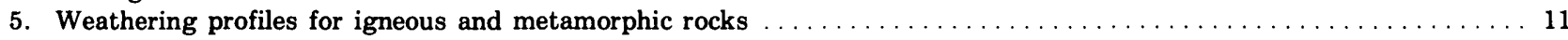

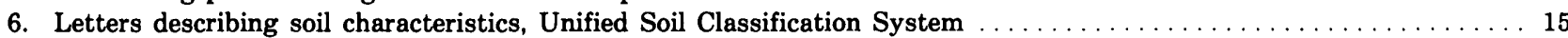

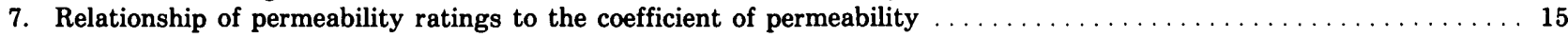

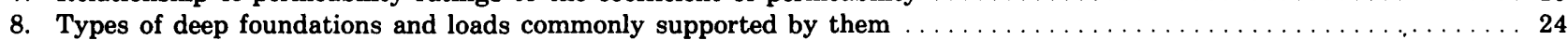

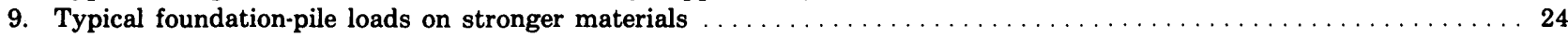

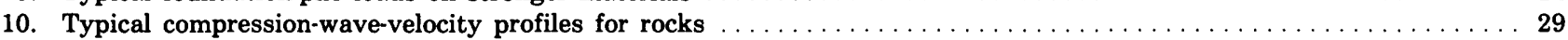

Qualitative and quantitative expressions of consistency of fine-grained soils and compactness of coarse-grained soils

$[<$, less than; $>$, greater than]

\begin{tabular}{|c|c|c|c|}
\hline \multicolumn{4}{|c|}{ Fine-grained soils } \\
\hline Consistency & Field description & $\begin{array}{c}\text { Unconfined } \\
\text { compressive } \\
\text { strength } \\
\left(\mathbf{k g f} / \mathrm{cm}^{2}\right)\end{array}$ & $\begin{array}{c}\text { Standard } \\
\text { Penetration Test } \\
\text { resistance } \\
\text { (blows/ft) }\end{array}$ \\
\hline Very soft -..--- & $\begin{array}{l}\text { Easily penetrated several inches by } \\
\text { fist. }\end{array}$ & $<1.0$ & $<2$ \\
\hline Soft ---------- & $\begin{array}{l}\text { Easily penetrated several inches by } \\
\text { thumb. }\end{array}$ & $1.0-2.0$ & $2-4$ \\
\hline Medium -..-- & $\begin{array}{l}\text { Can be penetrated several inches by } \\
\text { thumb with moderate effort. }\end{array}$ & $2.0-4.0$ & $4-8$ \\
\hline Stiff ------ & $\begin{array}{l}\text { Readily indented by thumb but } \\
\text { penetrated only with great effort. }\end{array}$ & $4.0-8.0$ & $8-15$ \\
\hline Very stiff ------ & Readily indented by thumbnail -.-.-- & $8.0-16.0$ & $15-30$ \\
\hline Hard -- --- & Indented with difficulty by thumbnail & $>16.0$ & $>30$ \\
\hline \multicolumn{4}{|c|}{ Caarse-grained soils } \\
\hline & Compactness & \multicolumn{2}{|c|}{$\begin{array}{l}\text { Standard Penetration Test } \\
\text { resistance (blows/ft) }\end{array}$} \\
\hline & 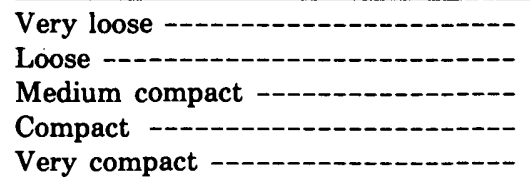 & $\begin{array}{r}< \\
4 \\
10 \\
30 \\
>\end{array}$ & \\
\hline
\end{tabular}

\section{Conversion factors}

\begin{tabular}{|c|c|}
\hline Metric unit & English unit \\
\hline 1 meter $(\mathrm{m})$ & $=3.28$ feet \\
\hline 1 centimeter $(\mathrm{cm})$ & $=0.39$ inches \\
\hline $1 \mathrm{~meter} / \mathrm{second}(\mathrm{m} / \mathrm{s})$ & $=3.28 \mathrm{feet} / \mathrm{second}$ \\
\hline 1 kilogram force (kgf) & $=2.20$ pounds \\
\hline 1 kilogram force $/$ centimeter ${ }^{2}\left(\mathrm{kgf} / \mathrm{cm}^{2}\right)$ & $=2048$ pounds $/$ foot $^{2}$ \\
\hline 1 kilogram force $/$ centimeter $^{3}\left(\mathrm{kgf} / \mathrm{cm}^{3}\right)$ & $=0.062$ pounds $/$ foot $^{3}$ \\
\hline
\end{tabular}




\title{
RELATIONSHIPS BETWEEN GEOLOGY AND ENGINEERING CHARACTERISTICS OF SOILS AND WEATHERED ROCKS OF FAIRFAX COUNTY AND VICINITY, VIRGINIA
}

\author{
By STEPHEN F. Obermeier and William H. LANGER
}

\begin{abstract}
This report describes, in map-related format, the engineering properties and behavior of soils and weathered rocks in and near Fairfax County, Virginia. Our study showed that the engineering properties correlate rather directly with the parent materials, even when those materials are as diverse as they are here: the eastern part of the area is underlain by the unlithified sediments of the Coastal Plain Province, the central part by the crystalline rocks of the Piedmont Province, and the western part by the sedimentary and crystalline rocks of the Triassic Lowland Province. Because we consistently found this correlation between parent materials and engineering behavior despite the diversity of the soils and parent materials, we believe the results of our study can be extrapolated to other nearby areas with similar parent materials.

The report describes the soils and weathered rocks shown on the accompanying map, tabulates typical ranges of engineering properties, and discusses those properties in detail. The report has three main parts, reflecting the parent materials of the soils and weathered rocks, that is, nonconsolidated materials, sedimentary bedrock, and crystalline bedrock. These three parts are further subdivided according to the engineering properties of the materials. The report points out potential engineering problems as related to the specific geologic setting. Based on the setting, the report describes laboratory tests and field procedures used to determine specific engineering properties and to further define the problems; designs that might accommodate such problems are discussed. Because of the observed correlation between the characteristics of the parent materials and the observed engineering behavior, we discuss parent material, soil structure, weathered profile, engineering soil classifications, surface and internal drainage characteristics, suitability as compacted material, excavation properties, susceptibility to erosion, shear strength and compressibility, allowable bearing pressure, slope stability, and road-performance characteristics.
\end{abstract}

\section{INTRODUCTION}

This report presents generalized relationships between geology and the engineering characteristics of the soils ${ }^{1}$ and weathered rocks throughout Fairfax County,

\footnotetext{
'In this report, "soil" is used in the engineering sense, meaning all unlithified, particulate
} materials.
Va., and surrounding areas, including Arlington County and the towns of Alexandria, Falls Church, and Fairfax (fig. 1). The geology is related to the physiographic provinces in the area (U.S. Geological Survey, 1970, p. 60); the eastern part of the area is underlain by unlithified sediments of the Coastal Plain Province, the central part of the area is underlain by crystalline (metamorphic and igneous) rocks of the Piedmont Province, and the western part of the area is underlain by sedimentary and crystalline rocks of the Triassic Lowland Province. Most of the area of the Piedmont and Triassic Lowland Provinces in the study area is covered by soil and weathered rock which formed from in-place weathering of the underlying bedrock. These weathering products have physical and engineering properties which generally result from the unweathered rock from which they are derived. Coastal Plain sediments were transported to the area by water and have not been lithified. (These unlithified sediments are also called "nonconsolidated materials" in this report.)

The soils and weathered rocks in the study area have been divided into three major groups based on parent materials, for discussion of engineering properties. The parent materials are nonconsolidated materials, sedimentary rock, and crystalline rock. The map location (pl. 1) of each group conforms approximately to a physiographic province. Each of these groups is further subdivided (pl. 1) on the basis of significant differences in engineering behavior, which is controlled by the details of the geologic setting. The report describes mapped units and evaluates the weathered rock and soil units so that readers can anticipate the properties of each unit and infer engineering behavior for proposed uses. The report cannot replace thorough site or subdivision evaluation. Detailed field and laboratory investigations are necessary for final site evaluation and engineering design. 
2

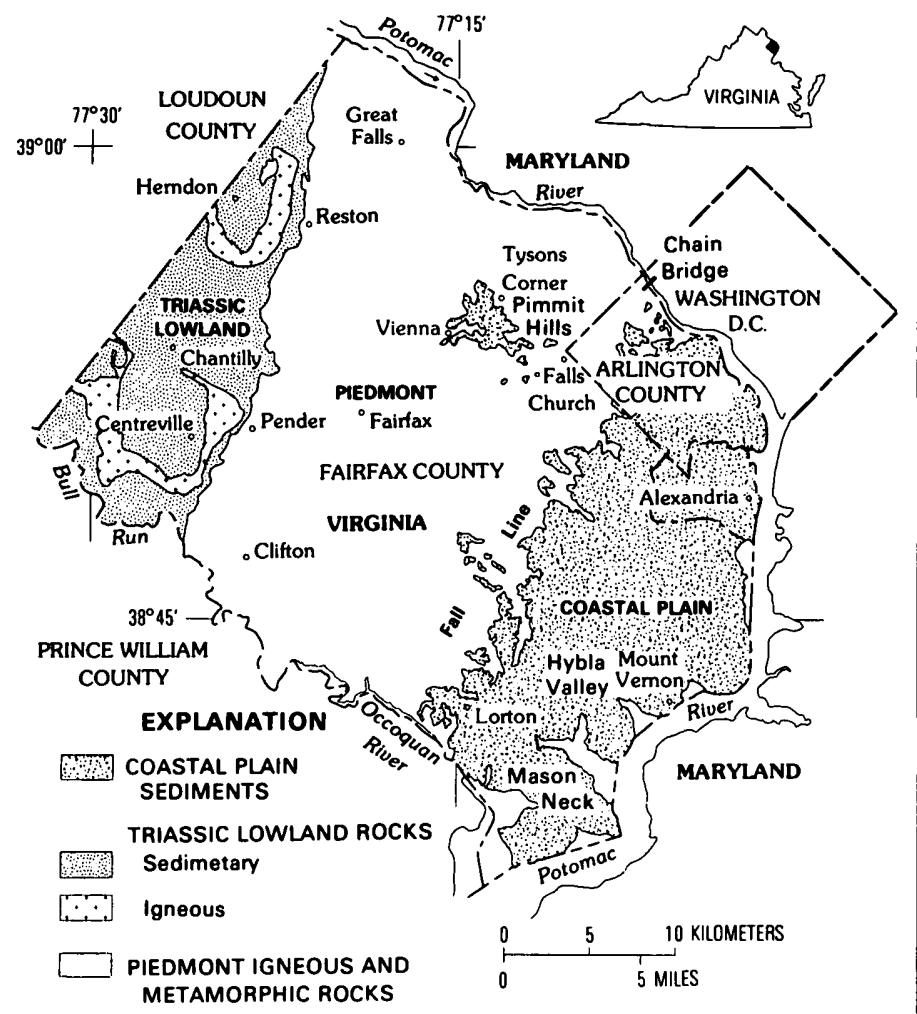

Figure 1.-Index and geologic sketch map showing Fairfax County and vicinity, Virginia.

Many terms used in this report have different meanings to geotechnical engineers and geologists. Where dual meanings are possible, standard engineering terminology is used; terms that are not standard engineering usage are defined. Terms for consistency and compactness are given in tables in the front of this report.

Acknowledgments.-Major sources of information for this report include "Surface Materials Map of Fairfax County, Virginia" (Langer, 1978); "Preliminary Bedrock Map of Fairfax County, Virginia" (Drake and Froelich, 1977); conversations with consulting engineers throughout the area and use of their unpublished engineering reports; subsurface investigation reports for the Washington, D.C., area METRO transit system (Mueser, Rutledge, Wentworth, and Johnston, General Soil Consultants, 1969, 1972, 1973, 1975); and testing data from the U.S. Geological Survey soil mechanics laboratory, Reston, Va.

The writers are grateful to Steve Garrison of Kidde Consultants, Manassas, Va.; Joseph Shuffleton, Law Engineering Testing Company, McLean, Va.; and Brian Beard, Schnabel Engineering Associates, Bethesda, Md., for their reviews and many helpful suggestions and contributions to the text.

\section{GEOLOGIC SETTING}

The study area (fig. 1) is in northern Virginia, bounded on the north and east by the Potomac River and on the southwest by Occoquan Creek and Bull Run. Its northwestern border is the Fairfax County-Loudoun County boundary. The area straddles the Fall Line (or Fall zone), which is a zone separating Cretaceous and younger unlithified sediments of the Coastal Plain Province from the Paleozoic and Precambrian igneous and metamorphic crystalline rocks of the Piedmont Province (Drake and others, 1979). The western part of the area is in the Triassic Lowland Province, which is underlain by sedimentary and crystalline rocks (fig. 1).

\section{PHYSIOGRAPHY}

The topography of the study area has moderate relief. The highest point is near Tysons Corner (altitude $158 \mathrm{~m}$ ), and the lowest point is at sea level (the surface of the Potomac River at Chain Bridge and downstream). The boundaries between the three physiographic prov. inces show no abrupt changes of topography. The sediments of the Coastal Plain feather out onto the Piedmont, and the gently undulating surface of the Triassic Lowland gradually merges with the more rolling Piedmont terrain. The area is drained by the Potomac River and its tributaries to the north and east, and by Occoquan River and its tributaries to the south.

The Piedmont is a rolling upland surface underlain by complexly folded and faulted crystalline rocks. Bedrock types are predominantly schist, phyllite, and gneiss, called the Wissahickon Formation, and lesser amounts of light-to-dark (felsic to ultramafic) igneous intrusive rocks. The bedrock has typically been deeply weathered in upland areas, and the land surface has been dissected by erosion. The depth of weathering generally exceeds $20 \mathrm{~m}$ and in some places exceeds $50 \mathrm{~m}$, but highly resistant rock types crop out at the surface in upland areas. All rock types crop out where there has been sufficient erosion.

The Triassic Lowland Province is characterized by gently undulating uplands which merge imperceptibly into broad valley bottoms. It is underlain by sedimentary and intrusive igneous rocks of Triassic to Jurassic age. Sedimentary bedrock is typically red interbedded pebble-cobble conglomerate, sandstone, and siltstone. These rocks are intruded and locally metamorphosed by diabase, a dark-gray medium-crystalline igneous rock.

The Coastal Plain Province is a lowland, sloping gently seaward (east), descending steplike from the Piedmont Province to the Atlantic Coast. It is underlain 
by nonconsolidated Cretaceous, Tertiary, and Quaternary sediments, which unconformably overlie the crystalline rocks of the Piedmont. The contact between the Coastal Plain sediments and the underlying Piedmont rocks slopes seaward at approximately $18 \mathrm{~m} / \mathrm{km}$. The sediments form a wedge beginning at the Fall Line and thickening southeastward to more than $180 \mathrm{~m}$ near Hybla Valley. The Cretaceous sediments are of fluvial (river) origin and consist of a complex sequence of deposits of interbedded sand, gravel, silt, and clay called the Potomac Formation. Near the Fall Line, the Potomac Formation is capped by terraces of Tertiary gravel and sand. These terraces range from 1 to $5 \mathrm{~km}$ wide and are locally as much as $20 \mathrm{~m}$ thick. Several erosional outliers occur just west of the Fall Line, at Tysons Corner and near Pimmit Hills, isolated from the main mass of Coastal Plain sediments. Near the Potomac River, at Hybla Valley and Mason Neck, Pleistocene estuarine and terrace deposits of silt, clay, sand, and gravel as much as $50 \mathrm{~m}$ thick fill large valleys cut into the Cretaceous sediments deposited by the ancestral Potomac River.

\section{GEOLOGIC HISTORY AND PROCESSES}

The discussion in this section of the report is based largely on the following: Drake and Froelich (1977); Drake and others (1979); Force (1975); Johnston (1964); Johnston and Salotto (1962); and Nelson (1976).

The history of the rocks in the Piedmont Province began with the deposition of sediments in a sea during Precambrian and early Paleozoic time (at least 440 m.y. ago). Submarine landslides reworked some of the materials, incorporating large blocks of older lithified or semilithified sediments. After lithification, the rocks were uplifted above sea level and were intruded by mafic and acidic or felsic magmas. Much later, in late Paleozoic time, compressional forces from the westnorthwest buckled the Earth's crust into mountains and compressed the beds into tight folds. This tectonism also created fractures, and other partings in the rocks, such as faults, shears, foliation, and parting planes.

From late Paleozoic time until the present, the rocks in the Piedmont have been weathered. Rainwater and ground water moving through fractures in the rocks react with minerals in the rocks, changing some of the minerals into clay and leaching (dissolving) others. Intense weathering throughout the Piedmont has produced saprolite, a soil-like material which retains the original foliation, joints, and other rock structures, yet is so weak that it can be dug using hand tools. The depth of weathering, mineralogy, and physical properties of the saprolite are controlled primarily by bedrock mineralogy and by fractures and partings in the rock.
Where saprolite occurs on slopes, the upper few meters may gradually creep downslope and accumulate as colluvium at the base of hillslopes. This reworked material is generally weaker and looser than the saprolite from which it was derived, and has markedly different physical properties.

The geologic history of the Triassic Lowland Province continues from the end of tectonic activity in the Piedmont. After the mountain building, a long period of erosion lowered the mountains. This period was followed by a period of tectonism which broke the Piedmont rocks and created a basin flanked by fault-block mountains. Coarse sediments were deposited near the basin margins as alluvial fans, and formed conglomerate which presently borders much of the basin. Finer sediments were carried farther into the basin where they were deposited in sandy mud flats or in playa lakes. Continued tectonism resulted in fluctuations in the gradients of rivers and concurrent changes in sediment type. Similarly, climatic fluctuations, particularly rainfall, changed the environment of deposition, thereby affecting sedimentation. These tectonic and climatic fluctuations resulted in interfingering and interlayering of the deposits. Sedimentation was interrupted many times by continued faulting and tilting of the rocks, and by igneous activity.

During Early Cretaceous time, gravel, sand, silt, and clay were deposited by rivers meandering along the inner edge of the Coastal Plain. These sediments, called the Potomac Formation, are characterized by crossbedding, channel fills, rapid pinching and swelling of beds, and abrupt changes in lateral and vertical size grading. Continued subsidence and tilting resulted in a gentle eastward dipping of the sediments. Base level changed during late Tertiary time, subjecting the area to erosion and then to fluvial deposition. During the late Tertiary, deposition of sand and quartz gravel by an ancestral river system formed broad alluvial terraces on the Potomac Formation sediments and the Piedmont rocks. These deposits are commonly called upland gravels. In this area, the upland gravels are a succession of five terraces that descend steplike to the southeast.

As base level changed and terraces formed, widespread slumping and sliding of Potomac Formation clay occurred until erosional escarpments reached an angle of stability. Each change in base level resulted in renewed instability of clay slopes, and renewed slumping and sliding.

Continental glaciers did not reach northern Virginia during Pleistocene time but did profoundly affect erosion and deposition in the area. At times of maximum glaciation, water was incorporated in the glaciers as ice, and sea level was lower than at present. Because of the 
lower sea level, the ancestral Potomac River and its tributaries cut deep valleys into the Coastal Plain sediments. As the glacial ice retreated, sea level rose, coarse basal gravels were deposited in these valleys, and later, the valleys were inundated and filled with finegrained sediments interlayered with peat and sand. Multiple glaciations resulted in the formation of three such terrace deposits along the Potomac River and its ancestral courses.

During the last 5,000-6,000 yrs, a rise in sea level of 5-10 m has drowned the valley of the Potomac River and the lower reaches of some of its tributaries, to the Fall Line. This drowning caused the deposition of finegrained alluvium, and estuarine and tidal-delta sediments in these valleys.

Many geologic processes continue today throughout the Fairfax County area. Erosion and deposition occur along streams and rivers, causing rapid changes at some places. Chemical and physical weathering and mass wasting are the primary, though much slower, processes occurring in the Piedmont and Triassic Lowland Provinces. In the Coastal Plain, the primary geologic processes are slumping and sliding of Quaternary sediments along the Potomac River escarpments, and creep, slumping, and sliding of Potomac Formation clays on hillsides. All of these processes can be accelerated by man's activities. In addition, man has altered much of the ground surface throughout the area by filling or excavating.

\section{OVERVIEW OF CHARACTERISTICS OF AND PROCESSES INVOLVING GEOLOGIC MATERIALS}

Geologic materials in the area (pl. 1) are grouped by similar physical properties and engineering characteristics. Each of the three groups conforms approximately to a geologic province. Nonconsolidated materials (table 1) associated chiefly with the Coastal Plain make up one group. Soils and weathered rocks developed on the sedimentary bedrock of the Triassic Lowland (table 2) make up another group, and soils and weathered crystalline rocks of the Piedmont and the Triassic Lowland (tables 3 and 4) make up a third group. Each group is further subdivided by differences in physical properties and engineering behavior.

Specific criteria used to differentiate these units for tables 1-4 are discussed below. Some of the most important weathering characteristics of geologic materials are discussed.

\section{NONCONSOLIDATED MATERIALS}

Nonconsolidated materials are deposits that behave as engineering soils, irrespective of degree of weathering or depth of burial. Nonconsolidated materials shown on plate 1 and table 1 are artificial fill, alluvium, terrace alluvium, colluvium and lag gravel, upland gravel, and Potomac Formation sand, silt, and clay. The primary factors for engineering categorization of nonconsolidated units (table 1) are strength and compressibility properties, and dominant textures. The relationships between the natural materials at the ground surface and the underlying deposits are shown in figure 2. The deposits are sand, gravel, silt, and clay that have been transported either by water, gravity, or man (artificial fill). Water-transported materials commonly are layered and contain particles of fairly uniform grain size (due to sorting) and include materials of the Potomac Formation (fig. 3), upland gravels (fig. $3 B$ ), terrace alluvium, and alluvium. Colluvium (fig. 4), the predominant gravity-transported material, accumulates chiefly by mass wasting on hillsides or at the base of hillslopes, but also forms a thin ubiquitous blanket over much of the study area.

Mechanical properties of unweathered nonconsolidated sediments such as density, undrained shear strength, and compressibility are generally related to age. Older sediments typically have a much stiffer consistency and are more compact than younger sediments. The oldest nonconsolidated sediments, the Potomac Formation, are generally so strong that they are difficult to excavate with hand tools except where weathered near the ground surface or where softened along faults or fractures. Alluvium, the youngest sediment, is so weak and wet at many places that it is unsuitable as a construction or foundation material and must be replaced with stronger material, or other measures must be taken to circumvent its adverse properties.

Standard engineering techniques for exploration and foundation design are usable for most nonconsolidated units (pl. 1). Exceptions are noted in the text and include units containing cemented and uncemented boulders; units containing iron oxide-cemented layers; units containing very thin zones of severely weathered and weakened soils within soils so strong that they are difficult to sample using conventional soil-mechanics exploration and sampling tools; and units in which joints and tectonically related sheared zones are within stiff to hard soils. Zones of softened soils, joints, and sheared zones are very weak and may cause slope instability, settlement of foundations, and other types of geotechnical problems. 


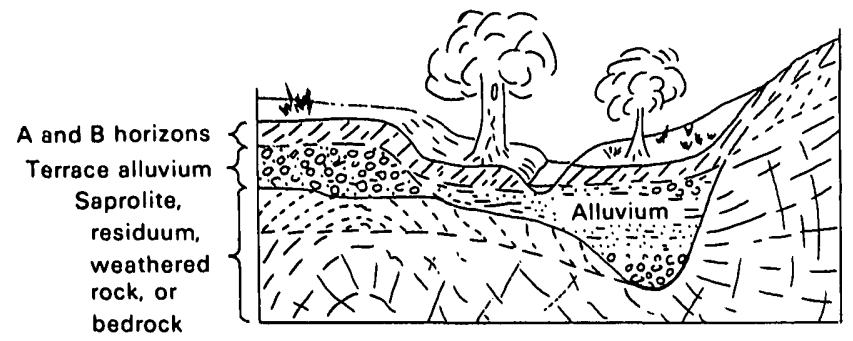

A. Alluvium and terrace alluvium

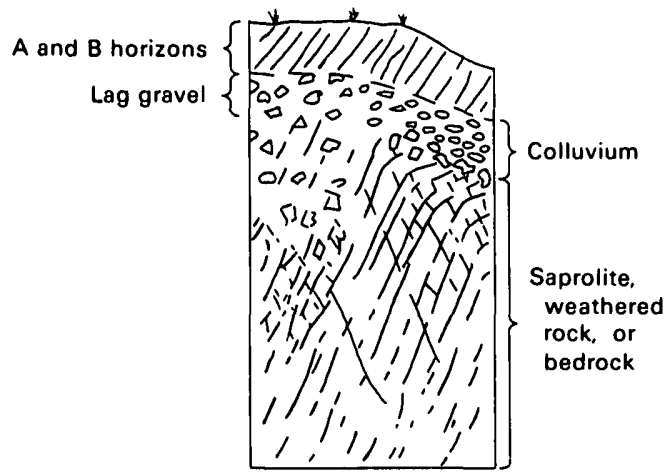

B. COLLUVIUM AND LAG GRAVEL

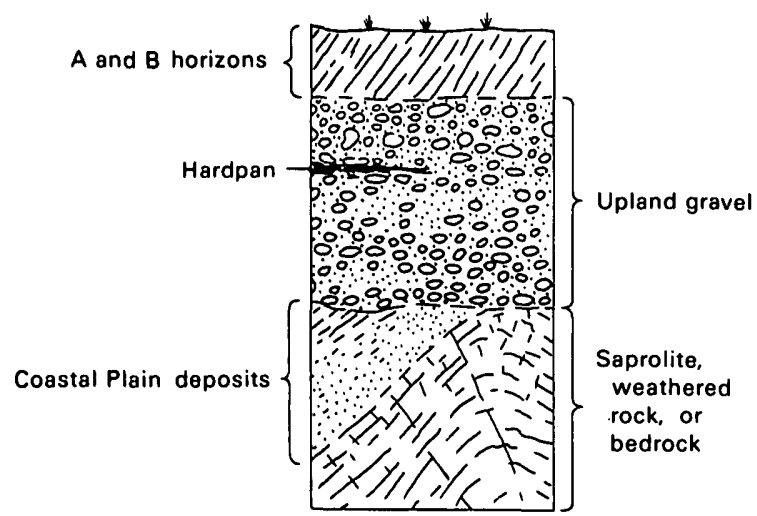

c. UPLAND GRAVEL

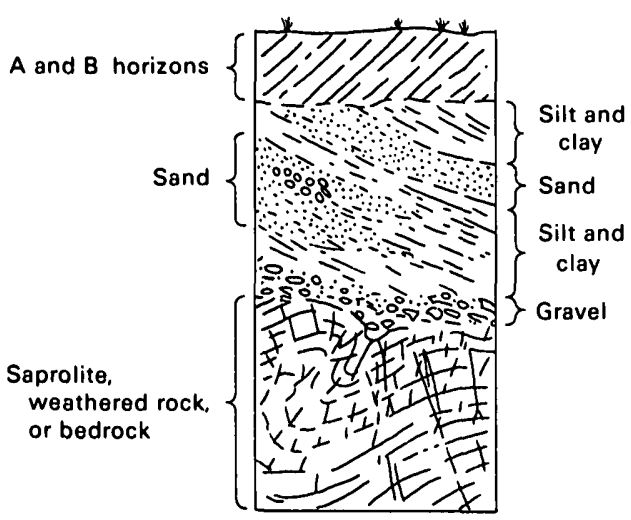

D. POTOMAC FORMATION

\section{SEDIMENTARY ROCKS AND THEIR WEATHERING PRODUCTS}

This group consists of the cemented and lithified sedimentary rocks of the Triassic Lowland Province, including shale, siltstone, sandstone, and conglomerate. These rocks commonly dip $5^{\circ}-25^{\circ}$ west-southwest, and the steepest dips are along the eastern edge of the study area. In places, they occur in interbedded sequences which alternate within a few centimeters to meters. Therefore, rock names on plate 1 and table 2 refer only to the dominant rock type in a sequence. For example, the rock type "sandstone" may contain thin interbeds of conglomerate, siltstone, and shale. The rocks in this group are divided into three units on plate 1 and table 2 , based on engineering properties within the weathered profile, such as dominant texture, strength, and compressibility. These units are siltstone, sandstone, and conglomerate. The geologic term "shale" is used in table 2 and for discussion, although such rock would normally be described as "mudstone" by engineering geologists because of lack of well-defined fissility.

\section{DEFINITION OF WEATHERED PROFILE}

Weathered products of sedimentary rocks (table 2) are derived from chemical weathering or from disaggregation of cemented or lithified strata. The dominant process and the products are dependent on the mineralogy of the bedrock. The general weathered profile on sedimentary rocks is shown in figure 5. Agricultural soil horizons are not used as a primary basis for discussion of the weathered products because the $A$ horizon has little or no engineering significance, and well-defined, deep $B$ horizon is developed only on shale.

On most sedimentary rocks, beneath the A. horizon, the weathered products typically grade from residuum to weathered rock to unweathered rock. Residuum is defined as rock weathered intensely in place and is soillike in consistency, containing less than 10 percent hard unweathered rock. Residuum commonly retains the structure of the parent rock with additional fractures and partings, except in the B horizon.

The term "weathered rock" means material containing more than 10 percent unweathered rock fragments.

FIgURE 2.-Diagrammatic cross sections showing relationships between nonconsolidated materials at the ground surface and underlying materials, Fairfax County and vicinity, Virginia. 


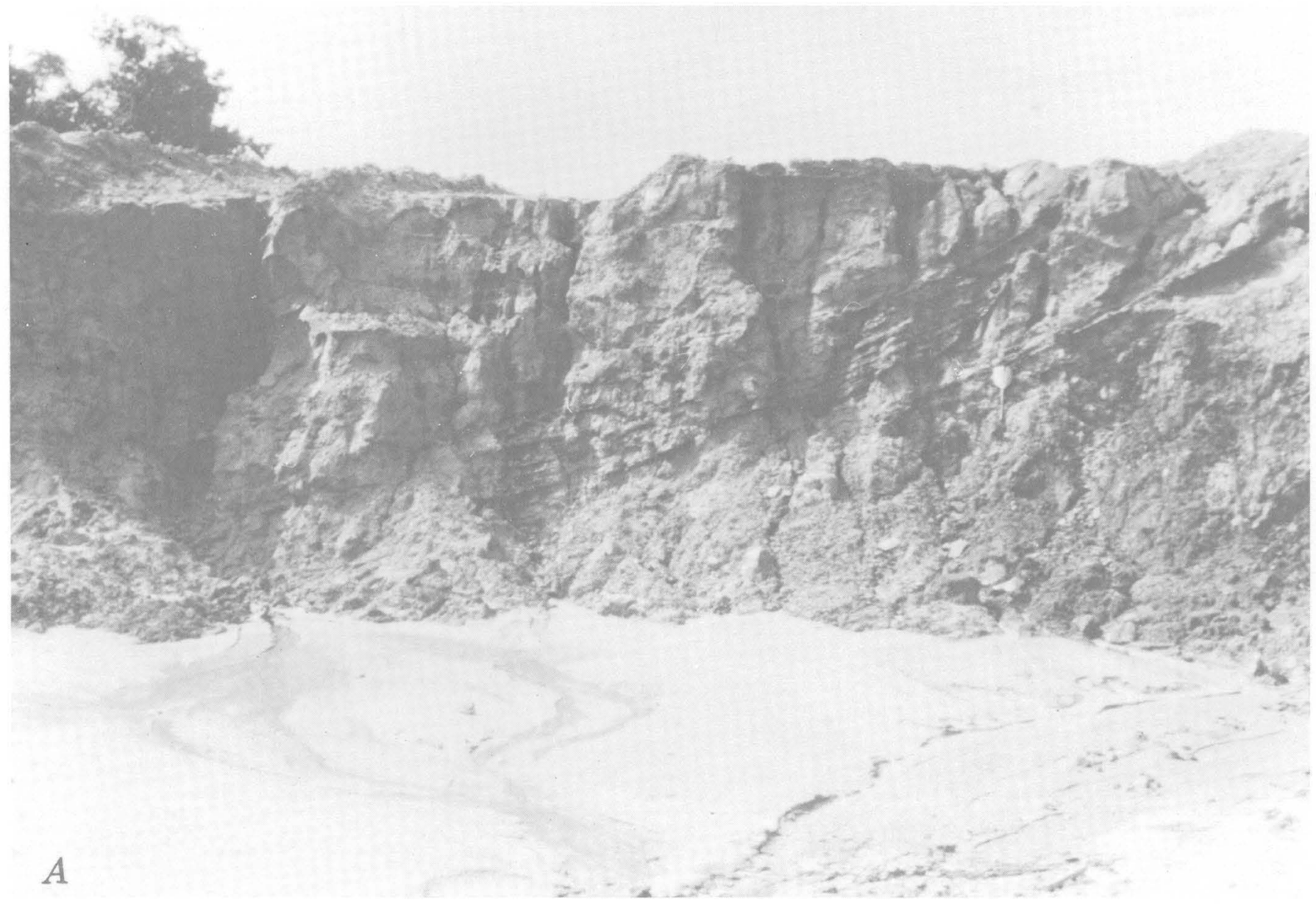

FIGURE 3. (above and facing page). $-A$, Potomac Formation sands, Fairfax County and vicinity, Virginia. Height of exposure is about $3.5 \mathrm{~m}$; and $B$, Potomac Formation silt and clay overlain by the upland gravel unit, Fairfax County and vicinity, Virginia. Height of exposure is about $5 \mathrm{~m}$.

Weathered rock generally has only a few more fractures and parting planes than unweathered rock, and the rocklike aspect in which joints and parting planes affect construction techniques or foundation and slope design is the most important engineering property. "Unweathered rock" shows no visible chemical or physical alteration or weakening of the parent rock.

\section{LITHOLOGIC CONTROL OF WEATHERED PROFILE}

The predominant means of weathering of the siltstone unit is disaggregation, combined with leaching of carbonate or ferruginous cement at some places. This finegrained unit is composed primarily of quartz and other minerals which are relatively stable chemically. Disaggregation and leaching are significant causes of weathering of the sandstone unit, also, but primarymineral decompositon and secondary-mineral formation (that is, clay minerals, iron oxides) are important chemical-weathering processes in the sandstone, because less stable minerals such as feldspars and biotite mica are commonly present and because the matrix of the sandstone is more permeable than that of the siltstone. The conglomerate unit commonly contains a large proportion of boulder- and gravel-size chunks of micaceous schist and has a coarse matrix of micaceous arkose. Chemical weathering of the feldspars and biotite mica in the mica schist and in the intergranular matrix is the predominant cause of weathering of this unit. Muscovite is commonly stable and remains, imparting a silvery sheen to the residue.

Residuum of the conglomerate unit is typically quite thick and makes up a large proportion of the weathered profile. The depth to unweathered rock may exceed $10 \mathrm{~m}$ but averages about $3 \mathrm{~m}$. The thickness of weathered products in the sandstone and siltstone units is commonly much less than in the conglomerate unit, 


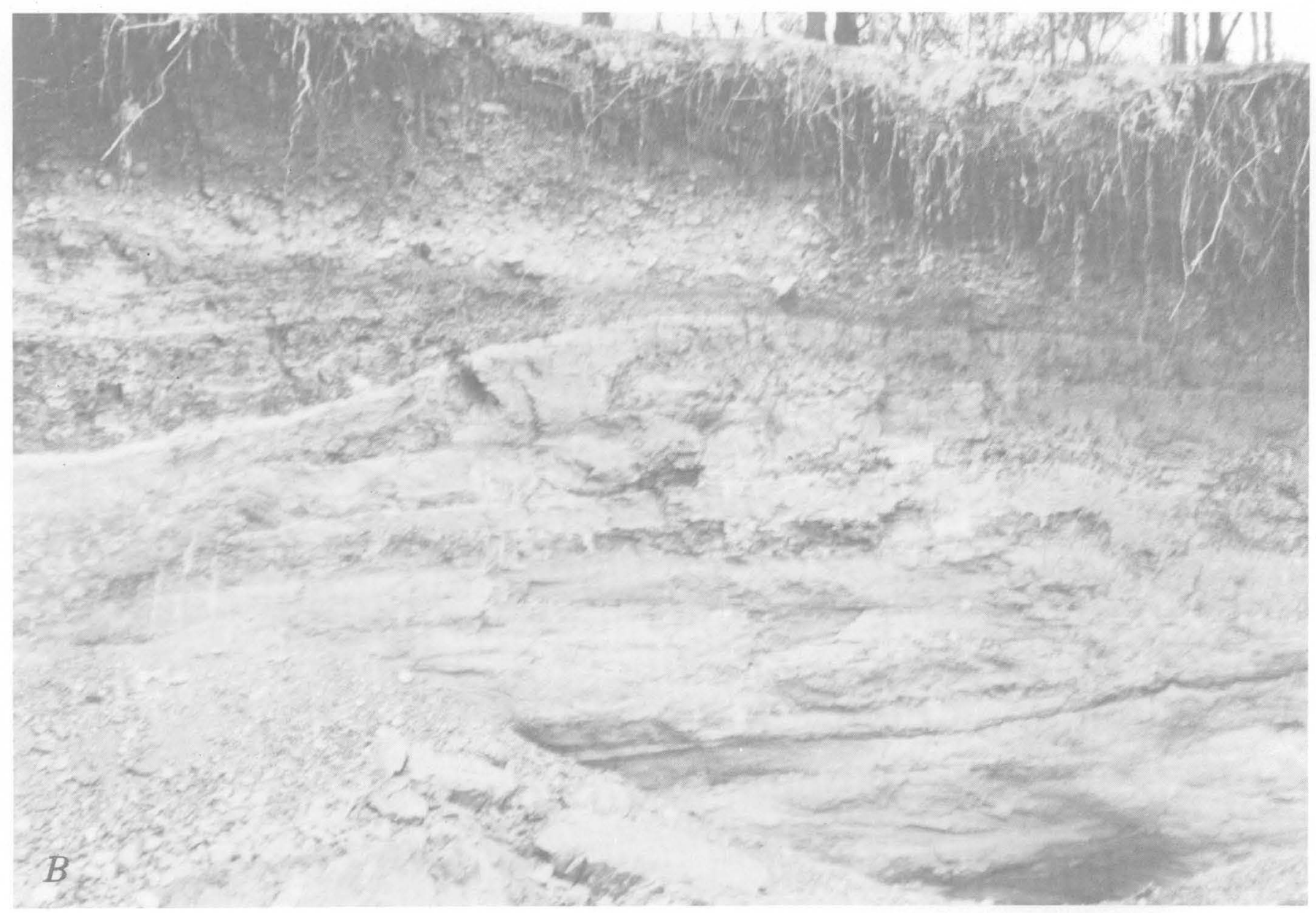

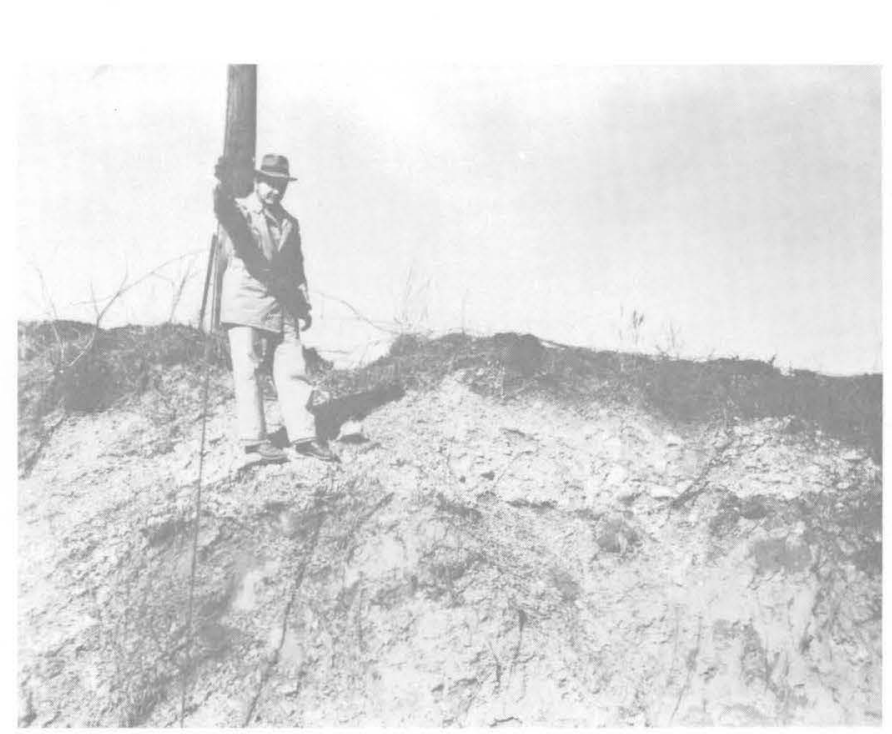

FIGURE 4.-Colluvium overlying saprolite formed from phyllite, Fairfax County and vicinity, Virginia.

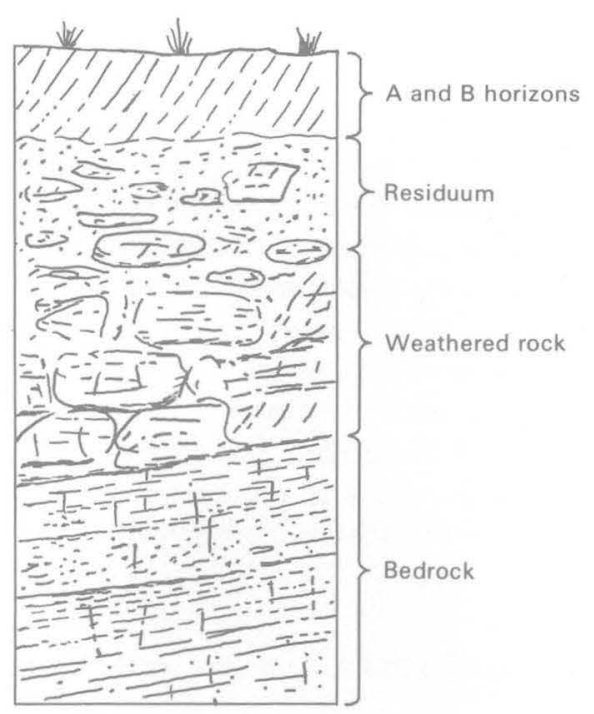

FIGURE 5.-Diagrammatic weathered profile on sedimentary rocks, Fairfax County and vicinity, Virginia. 


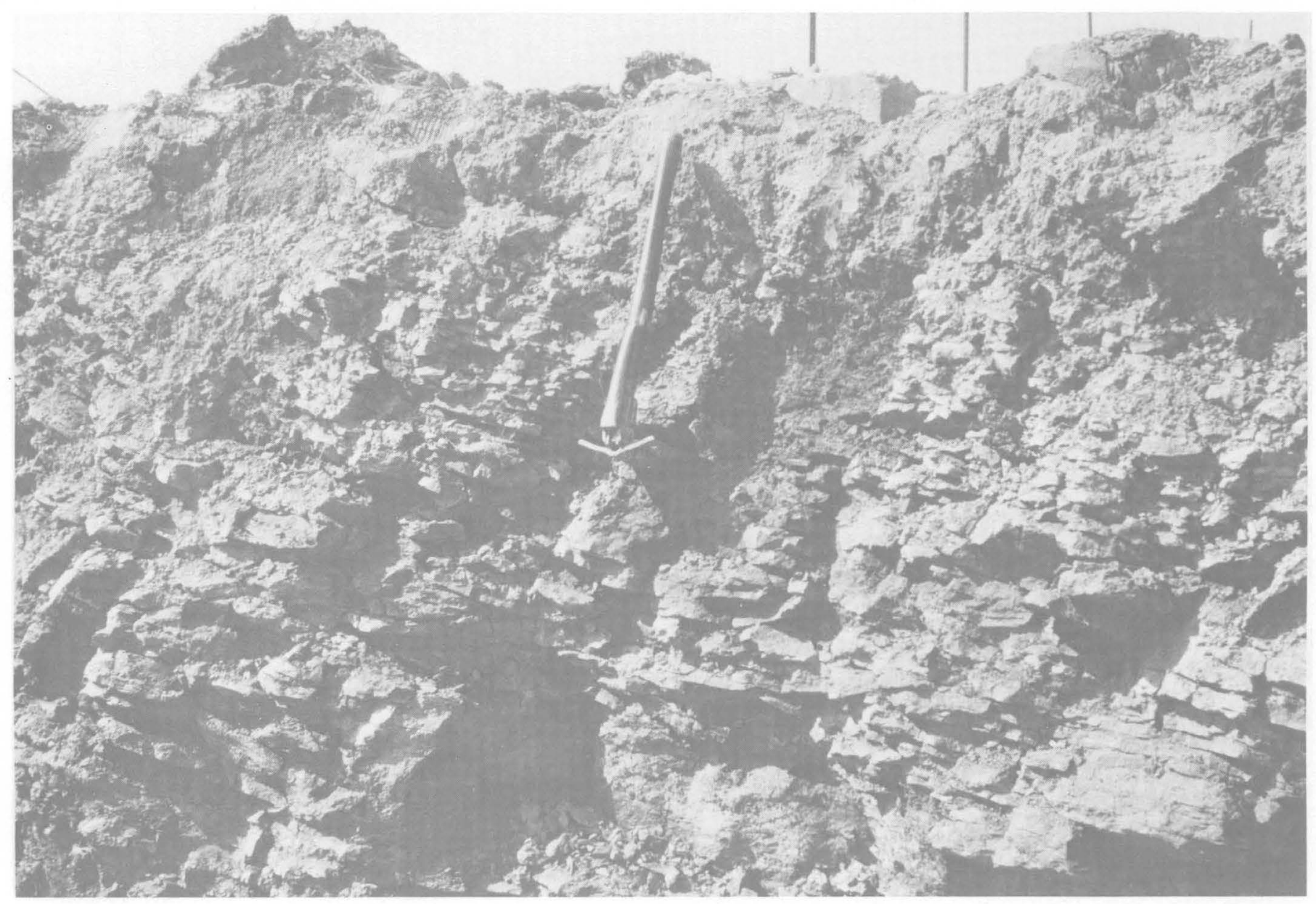

FIGURE 6.-Fractures in residuum and weathered rock on siltstone, Fairfax County and vicinity, Virginia. Contact between residuum and weathered rock is at the blade of the shovel.

averaging about $1.5 \mathrm{~m}$. Residuum of the sandstone and siltstone units also is typically much thicker than the weathered rock, but weathered rock in these units is commonly only about $0.3-1 \mathrm{~m}$ thick. Mechanical properties can change abruptly with depth where rocks of highly contrasting lithologies overlie one another, as is especially commonplace for the sandstone and siltstone units. Weaker, more weathered layers underlie much stronger strata at some places, an arrangement requiring careful field examination for foundation design and for seismic evaluations of rippability. Where residuum on shale has a deep B horizon, the weathering products are often highly plastic and generally weak, and thus contribute to many construction problems.

\section{JOINTS, FRACTURES, AND PARTING PLANES}

Joints in sedimentary rock of the Triassic Lowland Province are widespread and commonplace and are the type typically present in gently tilted, layered sedimentary rocks. They are perpendicular to bedding and commonly are not continuous planes across layers of greatly differing physical properties. Locally, though, continuous, parallel, closely spaced $(0.5-1 \mathrm{~cm})$, nearly vertical joints are intersected at $60^{\circ}-90^{\circ}$ by another nearvertical set. Apparently the continuous joints were tectonically created.

Joints, fractures, and parting planes are typically very widely spaced or not present in the conglomerate unit, and the residuum is massive. In the other units, irregular fracturing commonly resulted in flaggy chunks loosely held together in the weathered rock, and smaller fragments in the residuum (fig. 6). In both weathered rock and residuum, vertical and subhorizontal joints and fractures are commonly clay coated or oxide coated, and at some places are filled with as much as $0.5 \mathrm{~cm}$ clay; the fractures are normally open. The clay fillings have a medium-to-stiff consistency and can occur at least $3 \mathrm{~m}$ deep. Partings, continuous for many meters 
along original layering, are common in the siltstone unit, and in many places the rock is softened to a mediumto-stiff consistency at least $0.5 \mathrm{~cm}$ on both sides of the break. Partings are commonly found between highly contrasting lithologies. On the other hand, unweathered rock commonly has no fillings in these breaks in the rock, but the breaks may be stained. For trenches and cut slopes in residuum, parting planes or weakly cemented joints are generally weak zones of critical importance to stability.

North-trending faults along the eastern margin of the Triassic Lowland are associated with multiple zones of shearing near the ground surface (fig. 7). These zones range from a few millimeters to $3 \mathrm{~m}$ in thickness and contain sheared clay-rich material much weaker than the surrounding rock. This sheared material may be soft to very soft. Possible problems related to faults and shear zones include poor internal drainage, surface seeps, slope instability, and uneven settlement of deep foundations.

\section{CRYSTALLINE ROCKS AND THEIR WEATHERING PRODUCTS}

Rocks in this group include: contact-metamorphosed sedimentary rocks of the Triassic Lowland; polyfoliated micaceous schist, phyllite, and gneiss of the Piedmont crystalline terrain; and acid-to-basic igneous intrusive rocks of the Piedmont or Triassic Lowland. Contacts between rock types commonly are gradational rather than sharply defined. In addition, mapped contacts are approximate (pl. 1), in many places based on very limited exposures. Therefore, mapped contacts should be considered as zones separating rock types.

The units shown on plate 1 and tables 3 and 4 were chosen on the basis of significant variations in engineering properties within the weathered profiles. Depth of weathering, mineralogy, and physical characteristics of weathered products are controlled primarily by bedrock mineralogy and by zones which permit passage of water through the rocks, such as foliation, parting planes, joints, and sheared zones. The units are: hornfels; phyllite; gneiss, schist, and metagraywacke; ultramafic; mafic; granitoid rocks; diabase; and quartz. Except for quartz, all units have associated weathering products.

\section{DEFINITION OF WEATHERED PROFILE}

Weathered products (tables 3 and 4 ) are derived almost exclusively from inplace chemical weathering and leaching of bedrock, caused by rainwater infiltrating the ground and then moving through joints and other

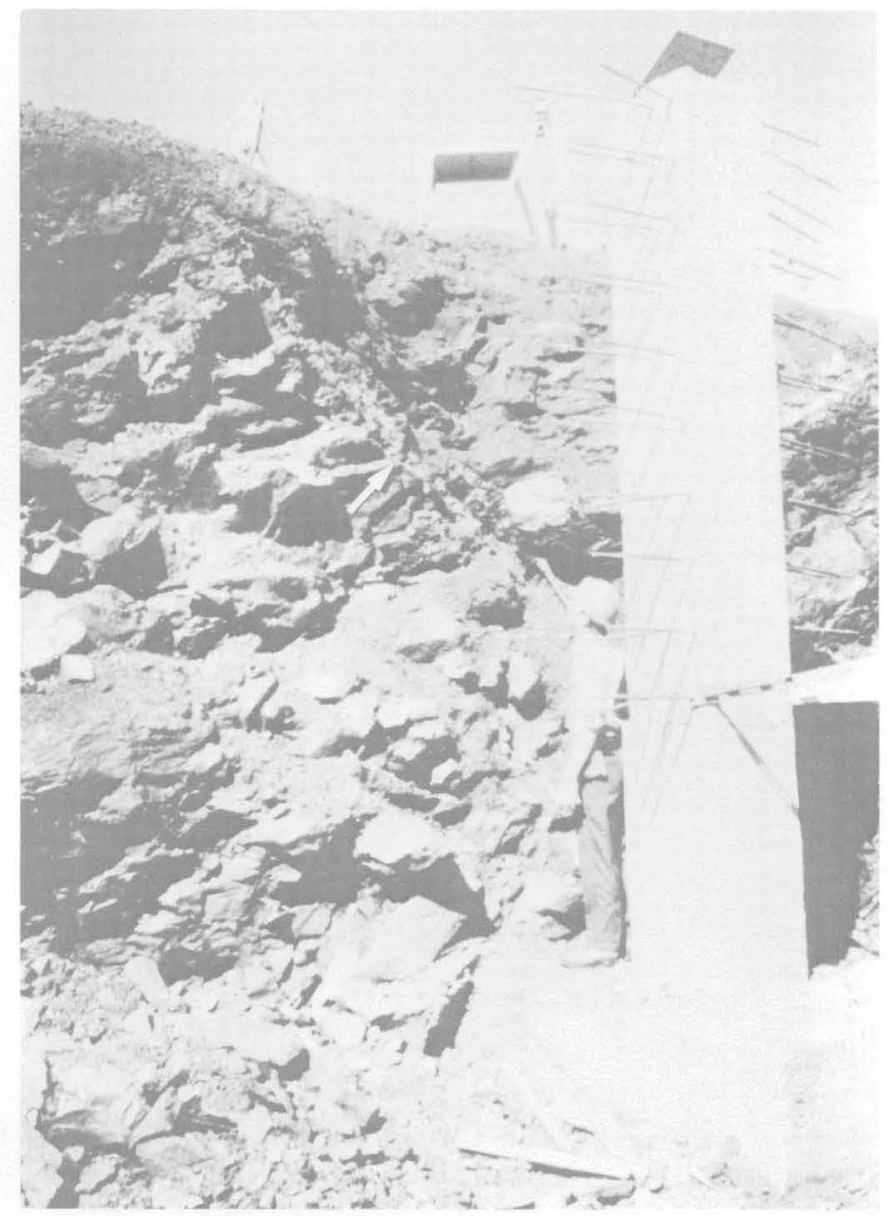

FIGURE 7.-Fault (arrow) exposed in excavation in siltstone, Fairfax County and vicinity, Virginia.

relatively permeable zones for a long time, probably tens to hundreds of thousands of years. A systematic vertical zonation of weathered products above the bedrock is commonly present, and each zone has different physical and engineering properties.

Very generalized relationships between the weathered zones and some engineering properties are shown in table 5, which shows three major zones: residual soil, weathered rock, and unweathered rock. Residual soil comprises the A and B horizons of the pedologist and also includes saprolite. Saprolite is sometimes called the $\mathrm{C}$ horizon but is defined here as the weathering product of crystalline bedrock that was decomposed in place to the consistency of soil. It can be dug or chopped using a hand shovel. Saprolite retains the original rock structure, foliation, and jointing, but the density can be as low as half that of the original rock. It has both soil-like and rock-like aspects, having the strength and compressibility of soil and the structure and fractures of rock. 
Some kinds of crystalline bedrock have weathering products whose $\mathrm{B}$ horizons are thick, highly plastic, and generally weak, and thus contribute to many construction problems. Saprolite is normally present directly beneath the $\mathrm{B}$ horizon. However, at some places in the uppermost 1-2 $\mathrm{m}$ there is a veneer of colluvium, or a zone where roots, organisms, or mechanisms such as frost action have apparently destroyed all evidence of original rock structure. For design of spread footings, the compressibility (a soil-like aspect) of saprolite is almost always the controlling factor, especially where rock structure has been destroyed. The physical properties of saprolite change gradually with increasing depth; the material becomes denser, less fractured, and stronger. There are many exceptions to this generalization, especially near the saprolite-weathered rock contact. The contact is commonly highly irregular and erratic, and slightly weathered rock may overlie more highly weathered rock. Beneath saprolite, weathered products typically grade into rather ill-defined zones of weathered rock and unweathered rock. Weathered rock characteristically has 10 percent or more core-stones. Although surrounded by weathered material, corestones are so hard they can only be broken with a hammer; they generally are flat and platy over metamorphic rocks, and are nearly equidimensional over igneous rocks (fig. 8). In the weathered-rock zone, minerals most susceptible to weathering are slightly altered, generally the amphiboles, pyroxenes, feldspars, and biotite. Unweathered rock has no visible alteration of minerals.

\section{LITHOLOGIC CONTROL OF WEATHERED PROFILE}

Weathered products depend primarily on the mineralogy and structure of the parent bedrock. To illustrate, granite and other felsic rocks are typically weathered much deeper than ultramafic rocks, and the strength and compressibility characteristics of the weathering products in the same weathering zones are vastly different for these rock types. These dissimilarities occur because some minerals weather more readily than others, and new minerals formed during weathering depend on bedrock mineralogy. Rocks containing abundant feldspars and quartz (felsic rocks) weather to kaolinite-bearing sandy soils, quartz being the sand fraction. Highly schistose feldspathic rocks weather to kaolinite-bearing silt. Rocks containing abundant mafic minerals (ultramafics) weather to montmorillonitebearing silty soils, and most weathering products are removed by solution (Cleaves, 1974; Leo and others, 1977). The clay content of the most highly weathered saprolite is generally 5-10 percent, but can be as much as 20 percent for mafic rocks.
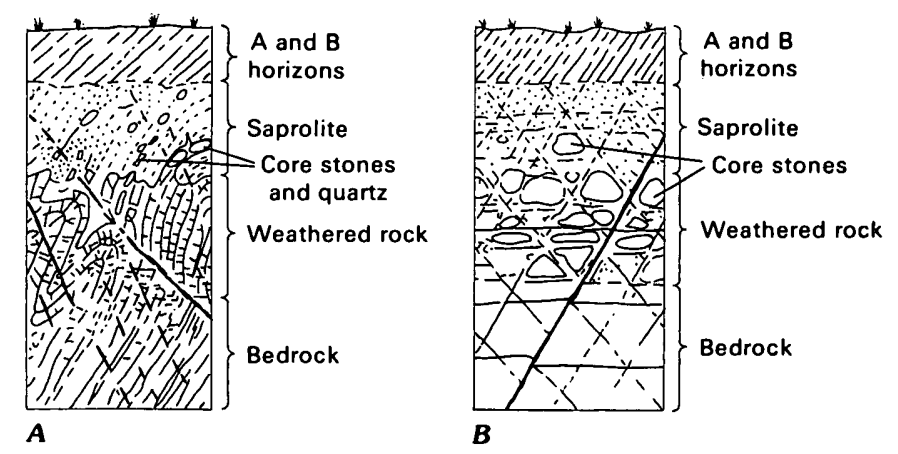

FiguRE 8.-Diagrammatic typical weathered profiles on crystalline rocks of the Piedmont Province, Fairfax County and vicinity, Virginia. $A$, Foliated metasedimentary rocks; and $B$, Massive metamorphic and igneous rocks.

In massive equigranular rocks such as granite and diabase, weathering occurs primarily along joints, whereas in foliated rocks weathering also occurs along planes of schistosity, cleavage, and mineral layering. One of the chief differences between saprolite derived from massive rocks and that derived from foliated rocks is the presence of many more residual boulders in the massive rock (fig. 9). Saprolite in schistose rocks has more parting planes and has hard layers of what were originally quartz-rich strata before metamorphism.

Saprolite is generally thickest on foliated medium- to coarse-grained rocks of felsic or intermediate composition, is somewhat thinner on mafic rocks, is very thin or absent on ultramafic rocks, and is absent on quartz. It is generally thicker and better developed on mediumgrained biotite-bearing pelitic schists than on finer grained sericite-chlorite phyllite. Quartz pods and veins are preserved unaltered in the saprolite profile, and the larger quartz bodies produce jumbles of residual boulders that commonly cap hills and ridges.

The maximum depth of weathered products is on hilltops, and on schistose, gneissic, and granitic rocks, the depth may exceed $50 \mathrm{~m}$ and is commonly $15-30 \mathrm{~m}$ (Froelich and Heironimus, 1977b). Ultramafic rocks such as serpentinite have no weathered products at many places. Over all crystalline rocks, the thickness is generally greatly diminished in valleys and near major drainage systems; only unweathered rocks are found in many stream beds.

Any comparison of the thickness of saprolite to weathered rock is a gross generalization; at many places saprolite is thicker than weathered rock, whereas elsewhere there is no saprolite on weathered rock. In 
TABLE 5.-Weathering profiles for igneous and metamorphic rocks

[Modified from Deere and Patton (1971); RQD, rock-quality designation (Deere and others, 1967); >, more than; <, less than; NX, nominal core diameter of 54.7 mm]

\begin{tabular}{|c|c|c|c|c|c|c|c|}
\hline Zone & & Description $^{1}$ & $\begin{array}{c}\text { RQD } \\
\text { (NX core, } \\
\text { percent) }\end{array}$ & $\begin{array}{l}\text { Core } \\
\text { recovery } \\
\text { (NX core, } \\
\text { percent) }\end{array}$ & $\begin{array}{c}\text { Relative } \\
\text { permeability }\end{array}$ & $\begin{array}{l}\text { Relative } \\
\text { strength }\end{array}$ & $\begin{array}{l}\text { Common } \\
\text { thickness } \\
\text { (m) }\end{array}$ \\
\hline \multirow[t]{3}{*}{$\begin{array}{c}\text { Residual } \\
\text { soil. }\end{array}$} & A horizon -- & $\begin{array}{l}\text { Consists of topsoil, roots, } \\
\text { organic material. Zone of } \\
\text { leaching and eluviation. } \\
\text { may be porous. }\end{array}$ & Not applicable & 0 & $\begin{array}{l}\text { Medium to } \\
\text { high. }\end{array}$ & Very low & 0.1 \\
\hline & B horizon --- & $\begin{array}{l}\text { Characteristically clay } \\
\text { enriched, also contains } \\
\text { accumulations of } \mathrm{Fe}, \mathrm{Al} \text {, } \\
\text { and Si. No relict } \\
\text { structures. }\end{array}$ & ---- do ---- & 0 & Low ------ & $\begin{array}{l}\text { Commonly } \\
\text { low. } \\
\text { Medium if } \\
\text { very dry. }\end{array}$ & 0.3 \\
\hline & Saprolite --- & $\begin{array}{l}\text { Relict rock structures } \\
\text { retained. Clay-bearing silt } \\
\text { or clay-bearing sand } \\
\text { grading to sand at depth. } \\
\text { Commonly micaceous, } \\
\text { feldspars and mafic } \\
\text { minerals altered to clays. } \\
<10 \text { percent core-stones. } \\
\text { Joints strongly cemented } \\
\text { with oxides at many } \\
\text { places. }\end{array}$ & $\begin{array}{l}0 \text { or not } \\
\text { applicable. }\end{array}$ & $\begin{array}{c}\text { Generally } \\
0-10\end{array}$ & Medium --- & $\begin{array}{l}\text { Low to } \\
\text { medium } \\
\text { (relict } \\
\text { structures } \\
\text { very } \\
\text { significant). }\end{array}$ & $1-15$ \\
\hline \multirow[t]{2}{*}{$\begin{array}{l}\text { Weathered } \\
\text { rock. }\end{array}$} & $\begin{array}{l}\text { Transition } \\
\text { from } \\
\text { residual soil } \\
\text { to partly } \\
\text { weathered } \\
\text { rock. }\end{array}$ & $\begin{array}{l}\text { Highly variable material, } \\
\text { soil-like to rock-like. Fine } \\
\text { material commonly fine } \\
\text { to coarse sand (gruss). } \\
\text { Feldspars and mafic } \\
\text { minerals partly altered. }\end{array}$ & $\begin{array}{l}\text { Variable, } \\
\text { generally } \\
0-50 .\end{array}$ & $\begin{array}{l}\text { Variable, } \\
\text { generally } \\
10-90 .\end{array}$ & $\begin{array}{l}\text { High (water } \\
\text { loss } \\
\text { common } \\
\text { during } \\
\text { drilling). }\end{array}$ & $\begin{array}{l}\text { Medium to low } \\
\text { where weak } \\
\text { and relict } \\
\text { structures } \\
\text { present. }\end{array}$ & $0.3-3$ \\
\hline & $\begin{array}{l}\text { Partly } \\
\text { weathered } \\
\text { rock. }\end{array}$ & $\begin{array}{l}\text { Rocklike, soft to hard rock. } \\
\text { Joints stained to slightly } \\
\text { weathered. Some } \\
\text { alteration of feldspars } \\
\text { and micas. }\end{array}$ & $\begin{array}{c}\text { Generally } \\
50-75 .\end{array}$ & $\begin{array}{l}\text { Generally } \\
>90 .\end{array}$ & $\begin{array}{l}\text { Medium to } \\
\text { high. }\end{array}$ & $\begin{array}{l}\text { Medium to } \\
\text { high. }\end{array}$ & $0.3-3$ \\
\hline $\begin{array}{c}\text { Unweathered } \\
\text { rock. }\end{array}$ & & $\begin{array}{l}\text { Trace to no iron staining } \\
\text { along joints. No weather- } \\
\text { ing of feldspar and micas. } \\
\text { No sheared zones. }\end{array}$ & $\begin{array}{l}>75 \text { (generally } \\
>90)\end{array}$ & $\begin{array}{l}\text { Generally } \\
100 .\end{array}$ & $\begin{array}{l}\text { Low to } \\
\text { medium. }\end{array}$ & Very high ${ }^{2}$ & $\begin{array}{l}\text { Not } \\
\text { applicable. }\end{array}$ \\
\hline
\end{tabular}

${ }^{1}$ These descriptions are the only reliable means of distinguishing the zones.

${ }^{2}$ Intact rock only, having no adversely oriented geologic structures.

general, though, saprolite is thickest between interfluves where it is considerably thicker than weathered rock, and it is thin or absent in valleys, where it has been eroded. The saprolite-weathered rock contact is typically highly irregular and difficult to define. The weathered-unweathered rock contact, although also irregular, can be approximately located at many places in the Piedmont because the relatively impermeable unweathered rock stops the downward flow of water, and ephemeral streams and seeps form along the contact.

JOINTS, PARTING PLANES, AND FOLIATION SHEAR ZONES

Saprolite retains the original foliation and jointing of the bedrock (fig. 10). Joints in saprolite are normally filled with manganese oxide or other oxides, or are clay

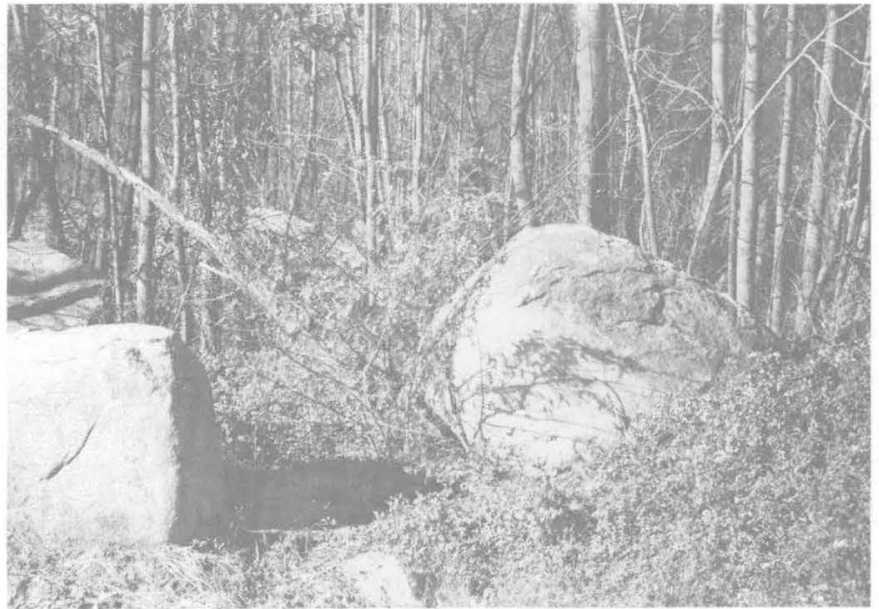

FIgURe 9.-Residual boulders on diabase, Fairfax County and vicinity, Virginia. Boulder is about $1.2 \mathrm{~m}$ in diameter. 
coated or clay filled. Locally, the oxides and clay may be sheared and slickensided. Parting planes and tectonically induced shear zones are commonly not cemented. For trenches and cut slopes in saprolite, parting planes, weakly cemented joints or sheared and slickensided joints are commonly weak zones of critical importance to stability.

Weathered rock generally has only a few more fractures and parting planes than unweathered rock. In weathered rock, the joints range from slightly cemented to merely stained, and the minerals most susceptible to weathering, such as feldspars, amphiboles, pyroxenes, and biotite, are chemically altered and leached, and the rock is thereby weakened. In both weathered and unweathered rock, the joints, fractures, and parting planes are the surfaces along which shearing failure is most likely to take place on steep slopes. Both shearing failure and closure of these natural breaks can cause failure of caissons or spread footings used for building foundations.

Unweathered rock has almost no joint fillings or coatings, although joints may be stained due to percolating ground water and oxidation. For most engineering design studies, strength along the joints or joint closure is of major importance. Joints in metamorphic and igneous rocks are generally closely spaced, have multiple orientations, and are continuous for long distances, and therefore are important to major construction activity. Well-developed planar joints are typically present in granite and other rocks that were not foliated (massive) at the time of emplacement (fig. 11). Well-developed partings in metamorphosed, folded rocks commonly follow original bedding (fig. 12). Intensely foliated rocks commonly have many closely spaced partings parallel to foliation.

In addition to joints, the crystalline rocks are locally cut by shear zones continuous for long distances (tens to hundreds of meters), along which the rock has been crushed, silicified, pyritized, chloritized, or argillized. Along some of these zones feldspars and micas have been altered and softened to the consistency of a weak soil, and the sheared, altered materials are as thick as $0.6 \mathrm{~m}$. The shear zones presumably mark local faults, but they generally cannot be traced beyond the limits of natural outcrops or artificial excavations. Most shear zones do not have displacements large enough to offset major lithologic units and are therefore not detectable by routine geologic mapping.

Foliated rocks also have numerous weak, sheared, mica-rich zones, parallel to schistosity (foliation shear zones of Deere, 1971), slickensided, and containing very slippery oxides (John and others, 1969) and seams of clay-rich gouge so weak that the gouge can be penetrated with the thumb (fig. 13). Foliation shear
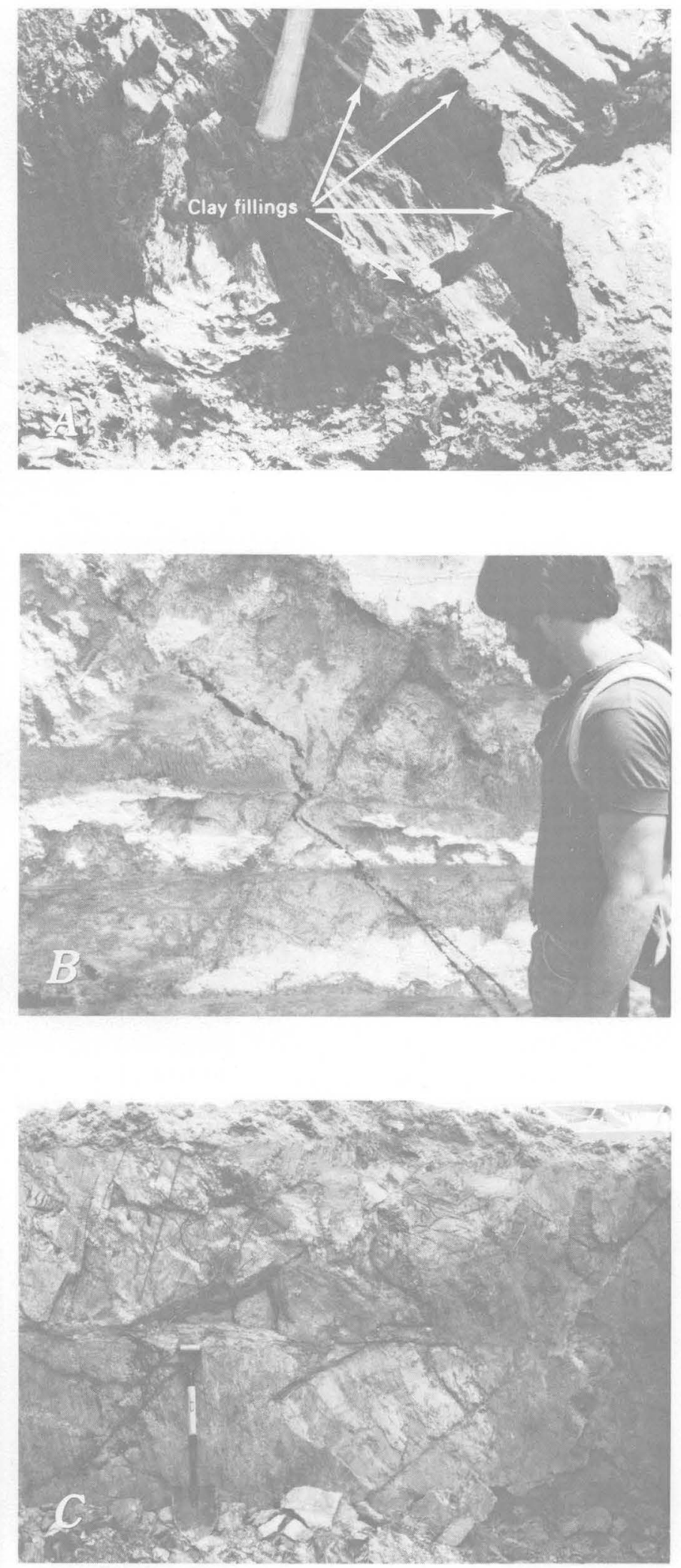

FIGURE 10.-Saprolite structure and joint-filling materials, Fairfax County and vicinity, Virginia. $A$, clay fillings in joints and on a joint surface; $B$ and $C$, oxide coating in joints. 


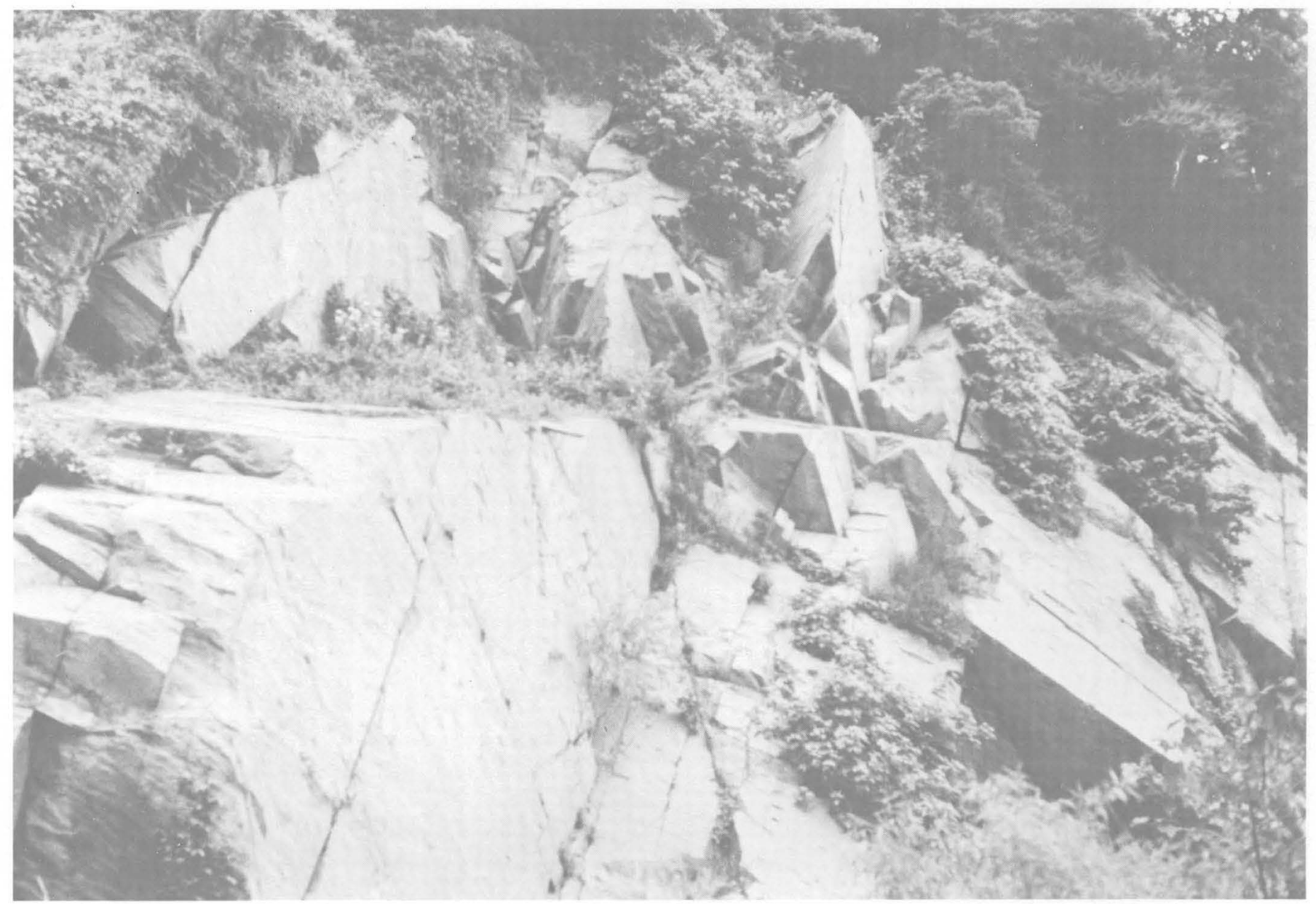

FIGURE 11.-Well-developed planar joints in an outcrop along the Potomac River of unweathered massive gneiss, Fairfax County and vicinity, Virginia. Exposure is about $25 \mathrm{~m}$ high.

zones are commonly $0.1-2 \mathrm{~m}$ wide, are continuous for long distances, and are in swarms as wide as $20 \mathrm{~m}$. These swarms are typically $100-300 \mathrm{~m}$ apart and are more closely spaced in highly foliated rocks, but are also commonplace at boundaries of contrasting rock types. Good exposures are in outcrops along the Potomac River underneath Chain Bridge. Much less common are weak sheared zones striking subparallel to foliation shear zones but dipping in the opposite direction (conjugate shear zones of Deere, 1971).

\section{LATERAL VARIATIONS IN WEATHERING}

Mechanical properties and the depth of weathered products commonly change abruptly laterally (in plan view) where there are steeply dipping strata of interbedded foliated rocks. Foliated strata generally dip steeply throughout the crystalline terrane, but abrupt lateral changes in mechanical properties and depth of weathering are most commonly present in zones intensely sheared by tectonism (that is, phyllonite zones) (Drake and others, 1979), though not sheared sufficiently to be foliation shear zones. These phyllonite zones vary in width from centimeters to kilometers and are commonplace throughout the gneiss, schist, and metagraywacke unit, and the phyllite unit (pl. 1). Within all metamorphic rock units, highly micaceous, weak sheared zones containing many parting planes are near the apices of folds. These zones are as much as $1 \mathrm{~m}$ thick. They are not sheared as intensely or weakened as severely as the foliation shear zones previously discussed.

Rock suites having abrupt lateral changes in mechanical properties are also present near the contacts of igneous bodies in the Piedmont. Here dikes of aplite $1 \mathrm{~m}$ or thicker cut across other rocks in some places. At some places, shattered or broken rock is present along the borders of the thicker aplite dikes. The aplite 


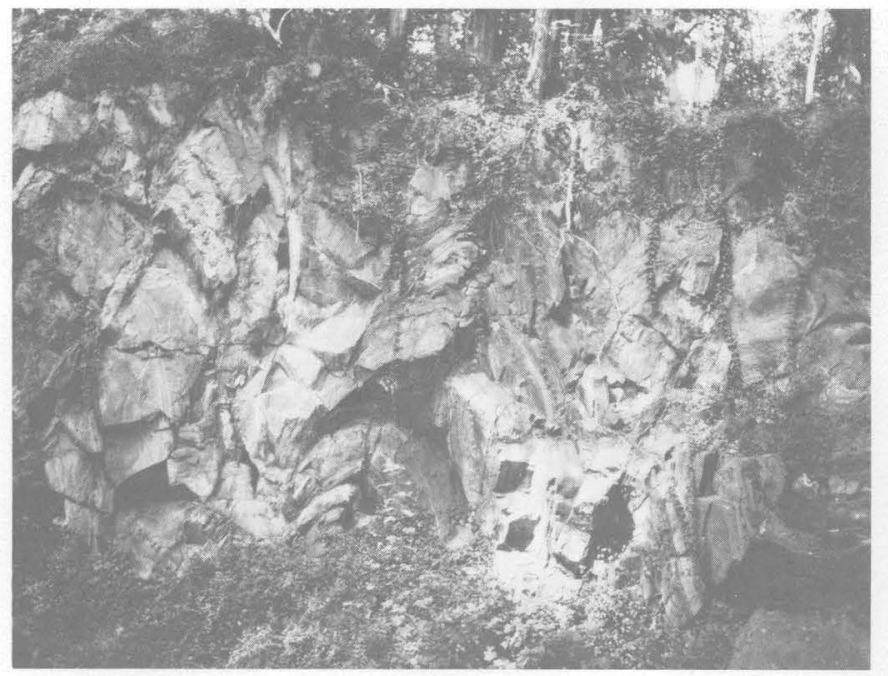

FIGURE 12.-Well-developed joints and other partings in metamorphosed, folded, unweathered metagraywacke, Fairfax County and vicinity, Virginia. Cliff is about $15 \mathrm{~m}$ high.

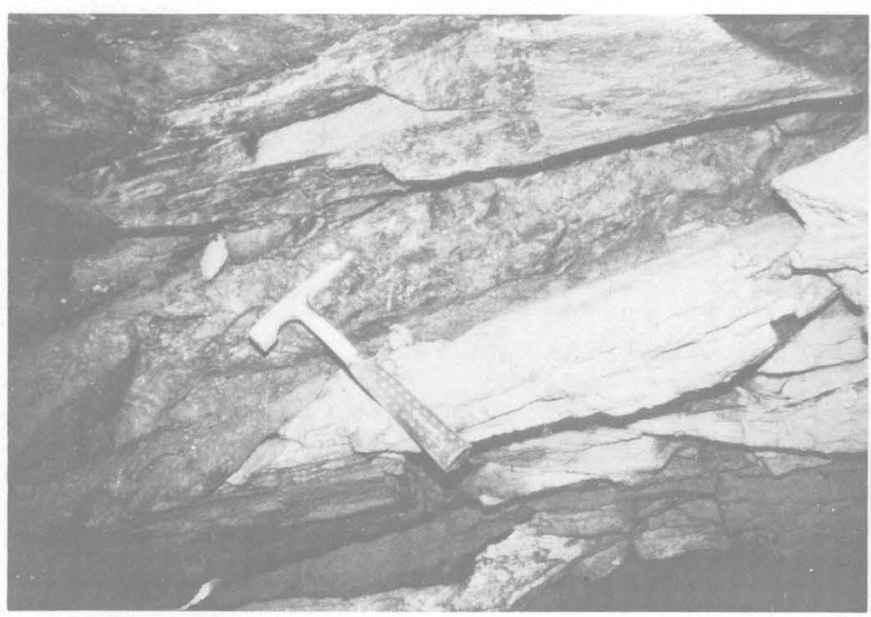

FIGURE 13.-Foliation shear zone in unweathered rock in a tunnel in Washington, D.C. Clay-rich gouge zone is at head of hammer.

is commonly weathered to cream, white, or red, highly plastic clay soil near the ground surface and is surrounded by stronger saprolite, weathered rock, or even unweathered rock. Although these dikes are most common near the borders of large igneous bodies, some crosscutting dikes are tens of kilometers away.

Veins, dikes, and pods of hard quartz many meters thick occur in the granitoid rock unit, in the gneiss, schist, and metagraywacke unit, and in the phyllite unit. These quartz pods may have formed from silica- saturated water associated with intrusion of the more acidic igneous rocks, or from silica-rich material concentrated during metamorphism. Small veinlets of quartz a few centimeters thick are very common and can present serious problems in engineering sampling and exploration of saprolite. The quartz veinlets commonly make it difficult to sample saprolite with Shelby tubes, and cause wide variations in Standard Penetration Test (STP) (American Society for Testing and Materials, 1978) blow counts.

In the western part of the county, some small diabase dikes about $1 \mathrm{~m}$ thick cut the sedimentary rocks of the Triassic Lowland Province. The dikes are commonly much more highly fractured and deeply weathered than the adjoining sedimentary rocks. The depth of saprolitized diabase can exceed $5 \mathrm{~m}$ in the dikes, whereas the depth to adjoining unweathered sedimentary rock is only 1-2 m. Small dikes are difficult to detect during exploration, yet can cause major engineering problems, requiring field inspection by the project engineer during construction.

Where large diabase bodies intruded sedimentary rocks in the Triassic Lowland, the mechanical and physical properties of weathered products on the metamorphosed sediments (hornfels) change laterally in a rather predictable way. The most highly metamorphosed rocks are adjacent to diabase, where contact metamorphism has hardened and recrystallized the original sediments, creating new minerals such as epidote or cordierite, in places. Some arkosic sandstones were altered to a granitelike rock, and changes in other strata are as striking. In general, the highly metamorphosed rocks are tougher and stronger, and have thinner weathered products than the less metamorphosed parent sedimentary rocks further from the diabase.

Abrupt lateral changes in the thickness of saprolite are also commonplace on some large bodies of massive rock which typically have a thin layer of saprolite, especially diabase. Saprolite on large bodies of diabase is commonly thin, but can be present to depths of 5$10 \mathrm{~m}$ along vertical and horizontal joints, and the saprolite, in places, encases unweathered rocks so hard they must be blasted to be broken. Large core-stones of diabase, as much as $2 \mathrm{~m}$ in diameter, are commonly on the ground surface.

\section{TABLES OF PHYSICAL PROPERTIES AND ENGINEERING GHARACTERISTICS}

The physical properties and engineering characteristics of the materials studied are given in tables 1-4. This section of the report explains how the data are related to various engineering and construction problems. Each 
TABLE 6.-Letters describing soil characteristics, Unified Soil Classification

\begin{tabular}{ll}
\hline First letter & \multicolumn{1}{c}{ Second letter } \\
\hline G, gravel & W, well graded \\
S, sand & P, poorly graded \\
M, silt & M, silty \\
C, clay & C, clayey \\
O, organic & L, low plasticity \\
Pt, peat & H, high plasticity \\
\hline
\end{tabular}

of the major headings below is also a column heading in tables 1-4.

\section{UNIFIED SOIL CLASSIFICATION}

This classification system (Wagner, 1957) uses the following letters as abbreviations for certain characteristics (table 6). Both particle size and plasticity properties are used as bases.

The most commonly used engineering soil classification systems, including the Unified system, have limited application to residual soils. Classification can indicate the engineering behavior of the $A$ and $B$ horizons. However, in saprolite and partly weathered rock zones,

the relict structure of the rock and the various physical properties accompanying incomplete weathering are not identified in the tests that are the bases for classification (Sowers and Richardson, 1983).

Saprolite may be classified by texture using standard procedures (Wagner, 1957), but the classification can be misleading. For example, micaceous saprolite can have sieve-determined grain-size gradations that resemble SM soils (table 6), because a large proportion of the so-called "sand-size" fraction is aggregates of weakly bound mica. This material may break down to smaller particles and feel slippery when rubbed between the fingers, and yet be nonplastic. Thus the soil should be classified as ML. Also, in some saprolite, physical breakdown of weathered minerals takes place during remolding or sieving, which changes the grain-size gradation, so two tests on identical samples have different results.

Some Potomac Formation clays are very hard and are gritty in appearance; the plasticity of some of these clays increases very markedly upon intense remolding, which breaks down the gritty clay peds. Some Potomac Formation sands may be misclassified, because they originally consisted of sand-size particles of feldspar which have subsequently weathered to clay minerals. Their plasticity can increase significantly upon intense remolding.

\section{TOTAL UNIT WEIGHT}

The data in tables 1-4 are the range of wet-unit weights common in naturally occurring soils. The weight of drainable water in fine-grained soils is almost always small as compared with the total unit weight, and thus no distinction needs to be made in total unit weight between soil above and below the ground-water table. For coarse-grained soils, a distinction is warranted at many places.

\section{DRAINAGE AND NATURAL-MOISTURE CHARACTERISTICS}

This heading in tables $1-4$ is subdivided into "Surface drainage," and "Internal drainage and natural moisture." "Surface drainage" describes the influence of permeability of the near-surface materials and the topographic setting on drainage conditions at the ground surface. "Internal drainage and natural moisture" rates the permeabilities (the term "permeability" is used in the sense described by Terzaghi and Peck, 1967) of the soils and notes the proximity of the water table to the ground surface or the anticipated naturally occurring moisture contents. Permeability is rated according to the system shown in table 7.

Permeability of metamorphic and igneous rocks in the Piedmont and of igneous rocks in the Triassic Lowland is, in general, systematically related to the weathering profile. Figure 14 shows an idealized weathering profile, relating relative permeability to the zones of weathering. Permeability of the clay-rich $B$ horizon is much less than that of saprolite immediately beneath. With increasing depth, the clay content of the saprolite zone and the cementation of joints decreases, increasing the permeability; porosity may also increase significantly with increasing depth in saprolite (Nutter and Otton, 1969).

Permeability in a particular weathered zone can be very dependent on the parent rock. Despite variations, saprolite normally has low permeability (table 7). Weathered rock commonly has low to high permeability, and unweathered rock commonly has low to very low permeability.

TABLE 7.-Relationship of permeability ratings shown in tables 1-4 to the coefficient of permeability

\begin{tabular}{ll}
\hline \multicolumn{1}{c}{ Rating } & Coefficient of permeability $(\mathrm{cm} / \mathrm{s})$ \\
\hline High & 0.01 and greater \\
Medium & $0.001-0.01$ \\
Low $-0.00001-0.001$ \\
Very low - & 0.00001 and smaller \\
\hline
\end{tabular}




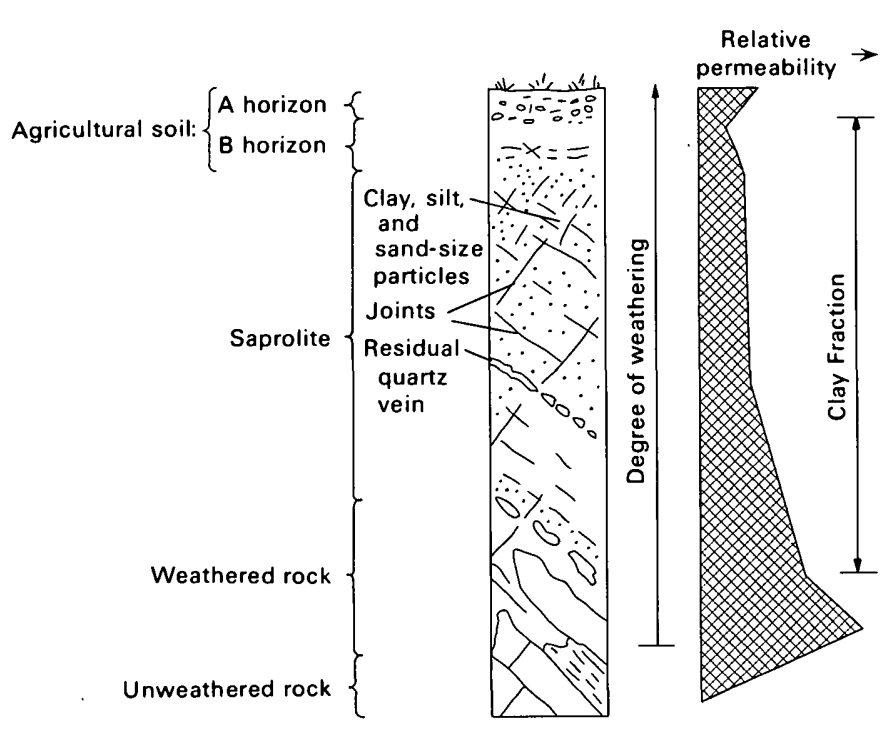

FIGURE 14.-Idealized weathered and permeability profile, showing unweathered crystalline rock grading upward into agricultural soil (modified from Nutter and Otton, 1969, p. 14).

Highest permeability commonly occurs near the base of the weathered rock zone, where joints are open, where there may be numerous parting planes, and where any saprolite probably has a sandy texture and contains little or no clay. Highest permeability is also in quartz veins that are shattered and fractured. Permeability in all these materials is typically very anisotropic, commonly ten times greater parallel than perpendicular to foliation (Sowers and Richardson, 1983). Permeabilitytest results on laboratory specimens commonly do not represent conditions in the ground. Therefore, laboratory data should be supplemented by field observations or pumping-test data.

Ground water is abundant at many places in the study area (Johnston and Larson, 1979; Reed and Obermeier, 1982), especially in the more deeply weathered Piedmont crystalline rocks and in the nonconsolidated materials of the Coastal Plain. It is also plentiful in some sheared and fractured zones in the Piedmont, even in the very slightly weathered rock.

The average annual precipitation in the study area is about $100 \mathrm{~cm}$ and is rather evenly distributed throughout the year. Local precipitation is the main source of ground water in the Piedmont. The water table is essentially a subdued reflection of the local topography, and the flow system is unconfined. The water table normally lies above unweathered rock in saprolite, and differences in permeability among colluvium, saprolite, and weathered and unweathered rock are subordinate to topography in controlling the location of the water table. Local variations in permeability are generally not large enough to cause extensive perched water tables or confined flow, although clayrich colluvium draped over slopes impedes flow at the base of slopes in some places. Sheared zones that cut through slightly weathered rock locally cause confined or artesian flow.

Typically, ground water is present throughout the lower part of the saprolite zone, and the water level may fluctuate several meters according to seasonal rainfall. The ground water in the partly weathered zone is in most places continuous with the overlying saprolite. However, impervious unweathered layers and highly permeable fractured zones distort the seepage patterns, producing local zones of pressures either higher or lower than in the saprolite zone. The upper part of the saprolite zone is often only partly saturated. The degree of saturation varies with height above the water table and the grain size, and with rainfall and evaporation.

Throughout the Piedmont, the ground-water table is almost invariably too deep to be of major concern to construction of houses and small industrial buildings on hilltops and on slopes greater than about 5-10 percent, except near the toe of slopes. However, during wet weather, especially in the spring, ground-water seeps and springs commonly occur along valley sides at places where unweathered rock is near the surface.

In the Triassic Lowland, the residuum and weathered rock zones of the siltstone and sandstone units are most permeable; the permeability is commonly low, but can be medium or rarely high (table 7). Weathered materials of these units commonly have many open joints and partings, which make laboratory-test data questionable. The conglomerate unit typically has low permeability throughout the weathered profile because of the abundance of clay and the lack of joints and parting planes. Laboratory data are probably of more, although still limited, value for this unit than for other Triassic sediments.

Ground water in the Triassic Lowland is less abundant in large quantities because the depth of weathering is generally more shallow than in Piedmont rocks, and sheared and highly fractured zones are not as common. In the Triassic Lowland, the ground-water table also generally follows the surface topography where residuum or saprolite is thick. However, at many places there is such a thin cover of weathered material that the water table is below the weathered-unweathered rock contact, especially in upland areas during dry parts of summer or fall. Ground water is generally of minor concern for most construction activities because the most permeable, water-saturated zones are thin and can be drained readily. In broad swales and above impermeable colluvial deposits, however, seasonal perched water tables may be present on all Triassic strata. These perched water tables are present from 
about November through March, and during prolonged rainy seasons. Areas having perched water tables can be detected during dry seasons by gray mottles in the $B$ horizon and in the underlying material.

The ground-water setting in the Coastal Plain contrasts sharply with that of the Piedmont and the Triassic Lowland. In the Coastal Plain, permeabilities of sands commonly are high, whereas permeabilities of clays commonly are low to very low. Confined or artesian conditions are common in the Potomac Formation, where they occur even at shallow depth. The water table on Potomac Formation deposits in the uplands is typically shallower in clay and thinly layered clay and sand than in massive sand bodies. Deposits younger than the Potomac Formation are generally so discontinuous laterally and so thin that artesian and confined conditions do not exist. The outcrop belts of porous and permeable units along the Fall Line are the principal recharge areas for the artesian aquifers of the Coastal Plain.

House, road, and sewer construction is often delayed by seasonally perched water tables in the Coastal Plain. At many places a seasonal perched water table occurs above a hardpan in the upland gravel unit, and above clay-rich Potomac Formation sediments. Perched water tables can be drained by French drain systems at many places in the area, which reduces or eliminates water problems in basements.

Many perched water tables occur in buried channels in upland areas of the Coastal Plain; these channels are commonly filled with clean, well-sorted sand, or sandor gravel-bearing sediments. The channels occur at many places, but highly permeable and porous gravelfilled channels are especially commonplace at unconformities separating geologic units. Control of ground water for both minor and major excavations in these upland areas generally does not require wells for removing large volumes of water from large areas; instead, effort should be concentrated on draining the channels intersected by the excavation. Thin, disconnected sand layers associated with lateral facies changes to silt and clay can also commonly be drained by permitting water to seep into excavations.

In broad swales and lowlands in the Coastal Plain, the ground-water table is near the ground surface at many places, especially where silt and clay layers are at shallow depths. Control of ground water generally involves pumping from wells or use of other expensive procedures.

\section{SUITABILITY AS COMPACTED MATERIAL}

Factors considered for use of naturally occurring soils as compacted material include: ease of drying wet materials, the relation of natural to optimum moisture content, plasticity of the materials, and mica content.

Highly plastic soils and organic materials are generally unsuitable as compacted material because of the difficulty of drying or wetting them in the field, the difficulty of controlling the moisture content, and other adverse properties. Soils of medium to high plasticity having natural moisture contents exceeding the optimum cannot usually be dried and compacted economically for road construction. Micaceous, silty soils so commonly present in the Piedmont are generally easily dried and wetted, and can normally be dried and used economically as compacted road fill, even where natural moisture contents are 8-10 percent above optimum; however, compaction moisture must be carefully controlled to achieve proper field compaction of these soils. Highly micaceous, fine-grained silt (that is, silt which has enough mica to make the soil feel slippery, even though the mica cannot be seen with the unaided eye) can be very difficult to compact, as it has a tendency to shove (displace laterally) during compaction, even at optimum moisture content. Cement is sometimes used to stabilize fine-grained micaceous silt so it will support heavy equipment.

Field compaction of micaceous silt according to $\mathrm{T}$ 180 (ASTM D-1557-70) (American Society for Testing and Materials, 1978a) density-moisture specifications is commonly extremely difficult. T-99 (ASTM D-69870) (American Society for Testing and Materials, 1978a) specifications are adequate for compacting soils for foundation loads as much as $2 \mathrm{kgf} / \mathrm{cm}^{2}$, beneath footings supporting houses and spread footings supporting light industrial buildings.

Field tests to determine the moisture content and density of micaceous soils should not be made with nuclear devices. Mica reflects fast neutrons, preventing absorption by hydrogen. Density measurements in micaceous soils can err as much as 10 percent, and moisturecontent measurements as much as $\mathbf{5 0}$ percent.

Hard, rocklike material of the siltstone unit sometimes weakens and softens after compaction according to rockfill specifications. Within a few years after compaction, this so-called "rock" may deteriorate to a soft, clay-rich material, which results in settlement and slope instability (fig. 15). We suspect that such deteriorating rocklike materials can be identified by means of a laboratoryconducted slake durability test or cyclic freeze-thaw test. Such deteriorating rock should probably not be used as backfill in utility excavations because of possible problems caused by settlement long after construction.

\section{EXCAVATION PROPERTIES}

The tables show characteristics of materials that are relevant to ease of excavation. The determination of the 


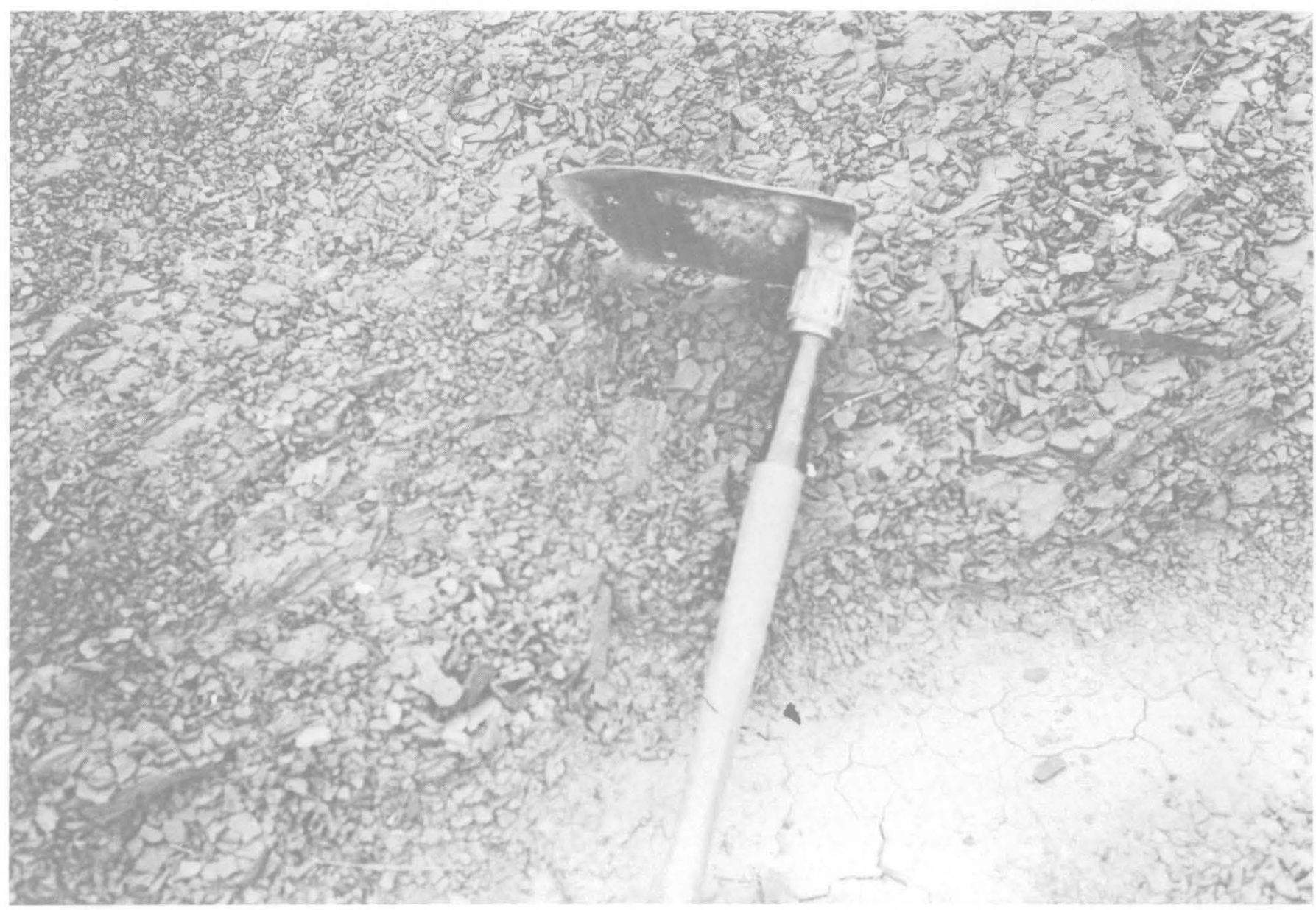

FIGURE 15.-Slaking and raveling of siltstone in road cut shows the rapid weathering of the rock, Fairfax County and vicinity, Virginia. Unweathered siltstone was excavated approximately 1 month before photograph was taken.

depth of weathered material that can be excavated with earth-moving equipment can be very difficult because the depth of weathering is so variable, especially on crystalline rocks. Rocks of the Piedmont and igneous rocks of the Triassic Lowland having SPT blow counts as high as about 100 can be ripped with heavy equipment (such as a Caterpillar D-9 $9^{2}$ bulldozer having a single tooth). Materials having higher blow counts, 100 or more per $15 \mathrm{~cm}$, can be ripped at some places where bedding planes or partings are closely spaced. In the Triassic Lowland, sedimentary rock units are probably too hard to be ripped if they cannot be augered with a $15-\mathrm{cm}$-diameter auger powered by a Mobile B-52 $2^{2}$ drill rig.

The depth of material that can be excavated in many of the geologic units described in this report is highly

${ }^{2}$ The use of brand names in this report is for identification only and does not imply endorsement by the U.S. Geological Survey. variable at a construction site. This variability is due to the presence of quartz bodies or sheared or highly foliated zones, or to highly contrasting bedrock lithologies. It is difficult or impossible to detect many of these situations prior to excavation, even by means of closely spaced drill holes.

Very large quartz bodies (map unit q) are shown on plate 1, but quartz bodies surrounded by weak saprolite are commonplace in the gneiss, schist, and metagraywacke unit (map unit gsm), and to a lesser extent in the granitoid rock (map unit g) and phyllite (map unit ph) units. Many intensely sheared zones are also present in all these units, and the gneiss, schist, and metagraywacke unit is highly variable in lithology at many places. Locally foliated or folded rocks of variable lithologies are common in the ultramafic (map unit u) and mafic (map unit $\mathrm{m}$ ) units. Many near-vertical shear zones, in which the materials have been weathered to saprolite, occur next to massive diabase. The depth of 
weathered material that can be excavated is commonly highly variable in the hornfels unit, and to a lesser extent in the sandstone unit, because of variable lithologies.

Unsupported walls can be destabilized by swelling and weakening of saprolite, especially where it is exposed to water. Micaceous saprolite is especially susceptible to weakening and can change from a hard to a medium or even soft consistency within 12 to $24 \mathrm{hrs}$ after an excavation is opened. Micaceous saprolite that is to support foundation loads should also be kept dry, because it can swell and become highly compressible, possibly causing large settlement of building foundations.

\section{SUSCEPTIBILITY TO EROSION}

Erosion properties are characterized for remolded materials and for naturally occurring materials at the ground surface.

All remolded, clean, silty, coarse-grained soils are easily eroded. These soils in the natural state are easily eroded unless slightly cemented. Coarse-grained materials containing enough clay to be designated GC or SC (table 6) are much more resistant to erosion.

Silty soils of the Piedmont and Triassic Lowland Provinces and of the colluvium and lag gravel unit are very easily eroded where disturbed by organic activity and by freezing and thawing, and wherever remolded by construction equipment. Undisturbed Potomac Formation clay can be very easily eroded if vegetation is removed (fig. 16).

Saprolite is susceptible to piping; holes having diameters as large as $1 \mathrm{~cm}$ can be found close to joints in some places. Tubes as large as $5 \mathrm{~cm}$ in diameter are probably widespread but not common in silty residuum of the Triassic Lowland; they may enlarge and undermine structures.

\section{SHEAR STRENGTH AND COMPRESSIBILITY CHARACTERISTICS}

Factors discussed in this category include types of tests most suitable for determination of shear strength, typical shear-strength values, testing techniques used for measurement of consolidation properties, and some typical compressibility data. Discussion is primarily about properties of the saprolite and residuum zones where shear strength and compressibility are of particular concern, except where these zones are so thin that houses and light industrial buildings are almost certain to be founded in underlying, much stronger weathered rock or unweathered rock zones.

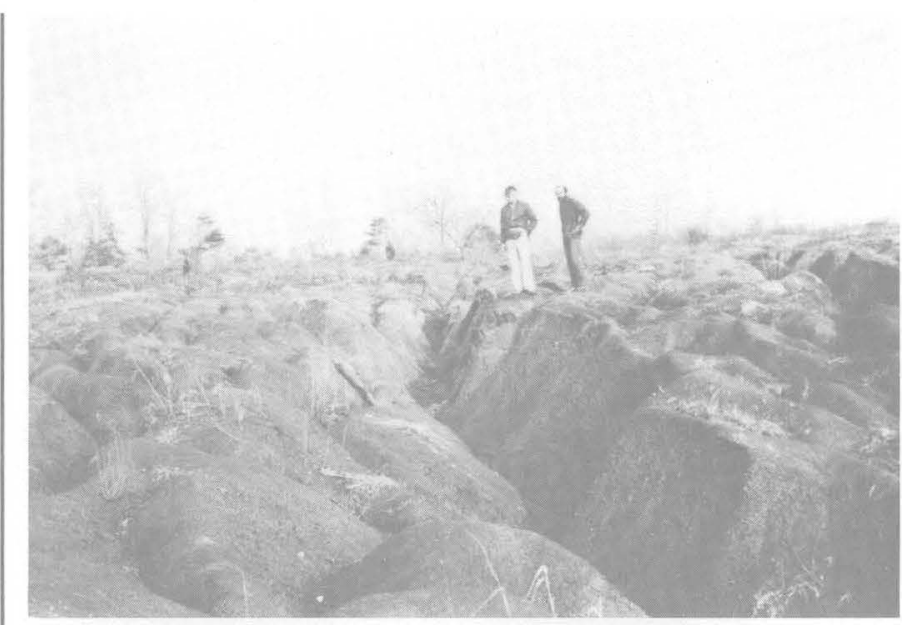

Figure 16.-Surface erosion on Potomac Formation clay, Fairfax County and vicinity, Virginia. Gullies shown here formed within $1 \mathrm{yr}$ after vegetation was removed.

\section{STRENGTH AND CHARACTERISTICS OF UNITS}

Selection of the method for strength testing depends on the material to be tested and the construction problem. Unconfined (U) compression tests are suitable for testing undrained homogeneous clays in the undrained state for construction-period problems. Unconsolidated undrained triaxial (UU) tests are required to restrain samples where failure in the undrained state may occur prematurely because of sand pockets, partings, fractures, or cracks; the test also partly compensates for sampling disturbance. Consolidated undrained triaxial (CU) tests or simple shear tests can be used to estimate the shear strength of weak, fine-grained soils which drain and strengthen somewhat during the construction period.

Direct shear tests are required to determine drained residual shear-strength parameters; direct shear tests can also be used to determine the strength properties along planar joints. Drained triaxial (CD) tests are used to determine shear-strength parameters for design of permanent slopes in some geologic settings where the soils are overconsolidated, and where failure of the slope would be in drained shear.

Homogeneous clays suitable for unconfined compression testing are generally present only in nonconsolidated materials of the Coastal Plain. UU tests are usually appropriate for construction-period problems in the alluvium and colluvium and lag gravel units, and sand, and silt and clay units in the Potomac Formation containing slickensides and joints. UU tests should normally be used for testing saprolite and residuum for construction-period problems because of the multiple 
weaknesses caused by fractures, parting planes, and preferential weathering, and because of the positive pore-water pressure commonly developed during shearing of nearly saturated samples. UU test data on samples that are not nearly saturated may be misleading; the materials may be in a state of suction and thus be stronger than they are in the field after a rainy or wet period.

Long-term failure of slopes in the highly plastic silt and clay of the Potomac Formation is one of the most serious design problems in the area. Where unweathered, the clay and silt are highly overconsolidated and very stiff, and are typically moderately to highly susceptible to shrinking and swelling (Obermeier, 1979). These properties alone pose difficult problems for geotechnical engineering design. Subhorizontal weak, weathered zones, faults and joints, highly variable strength properties of and localized artesian ground water in sand lenses, and water in joints and faults add further to the engineering problems. The peak shear strength of unweathered Potomac Formation soils (clay, silt, and sand) is commonly much greater than the strength of intensely weathered and softened soils; the peak strengths can differ by a factor of 10 ; figure 17 shows these relationships schematically. Based on local experience, residual shear-strength parameters may be required for many slope designs. Direct shear tests are recommended to determine residual shear-strength parameters of highly plastic clay or silt for long-term slope-stability problems. Residual shear-strength properties should be determined on samples that have precut shearing surfaces, or the strength properties should be measured on remolded samples, because intact samples can fail along surfaces not coincident with the plane of the shearing ring, which may cause strength values to be too high.

Direct shear tests are also normally used to evaluate drained-strength parameters of silt and clay of low plasticity and sand of the Potomac Formation; for these materials, though, shear-strength parameters selected for design of permanent cut slopes normally are between residual and peak, yet much above residual. Some designers use the peak drained shear strength of remolded soil (that is, the fully softened strength), consolidated under the weight of the overburden on the slope. This strength-test method is suggested only for soils that are not intensely fractured, or are not sufficiently plastic to become intensely fractured by shrinking and swelling.

Direct shear tests can also be used to determine shearstrength properties along joints in saprolite and partings in residuum.

Saprolite and residuum commonly behave as brittle materials, and intact samples have peak shear strengths

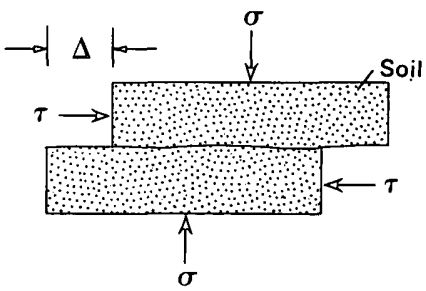

A. DIRECT SHEAR-TEST STRESS AND DEFORMATION CONDITIONS

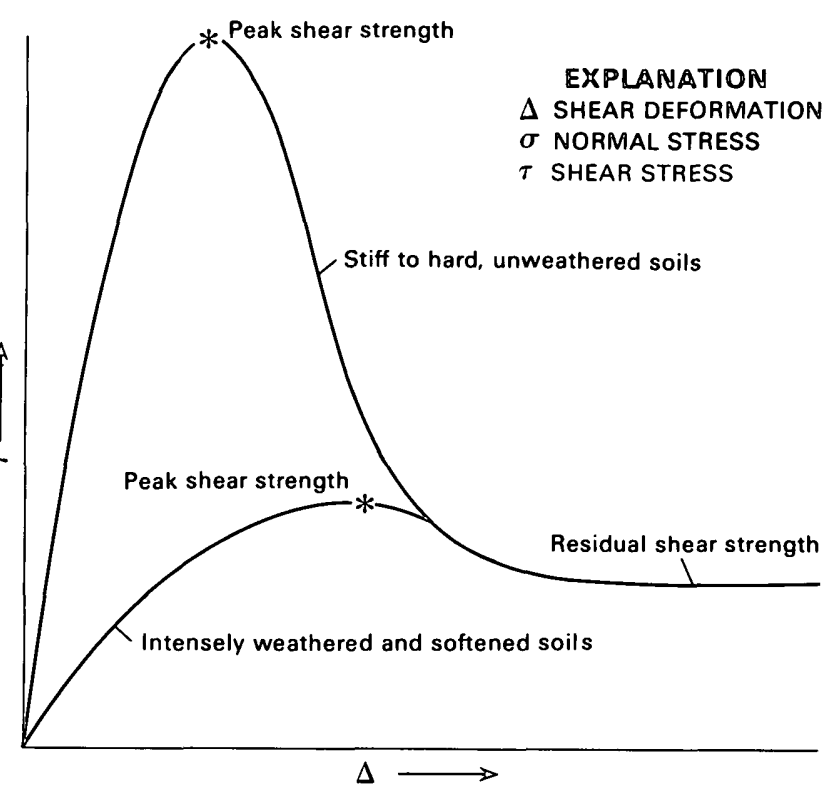

B. PLOT OF SHEAR STRESS VERSUS SHEAR DEFORMATION, UNDER CONSTANT NORMAL STRESS

FIGURE 17.-Typical strength relationships for drained direct shear tests on Potomac Formation soils, Fairfax County and vicinity, Virginia. $A$, Direct shear-test stress and deformation conditions; $B$, Plot of shear stress versus shear deformation, under constant normal stress.

(UU and $C D)$ at least 10-20 percent higher than the strengths at slightly greater strains. For constructionperiod excavations in saprolite where landslides could endanger lives, some designers use large-strain UU shear strengths, partly because of the difficulty of ensuring that the weakest zones have been found during exploration.

Throughout the Piedmont, the UU shear strength of nonplastic saprolite (the most common) and colluvium generally is about $0.5 \mathrm{kgf} / \mathrm{cm}^{2}$ in surface material affected by seasonal moisture changes and where the ground-water table is near the ground surface at the toe of slopes. Saprolite underneath colluvium is commonly very weak for a depth of 1-2 $\mathrm{m}$ beneath the contact. The UU shear strength of saprolite commonly increases fairly rapidly with depth to about $1 \mathrm{kgf} / \mathrm{cm}^{2}$ at $1.7 \mathrm{~m}$ and increases to $1.2-1.5 \mathrm{kgf} / \mathrm{cm}^{2}$ at $3-5 \mathrm{~m}$.

The premise of many local engineers that saprolite behaves as a strong friction material requires careful 
testing prior to acceptance. UU strength envelopes of saprolite and residuum are commonly strongly curved at confining pressures greater than the overburden weight, and become nearly flat at high confining pressures, probably because of the positive pore pressure developed during shearing. However, UU strength envelopes from samples of nearby materials can have slopes as high as $20^{\circ}-30^{\circ}$ even at high confining pressures, because the sample is slightly drier or has a different texture. UU test data are normally close approximations of the undrained shear strength for bearing-capacity design. However, UU data must be used with caution in evaluating materials, if the samples are not almost saturated during testing. Unsaturated samples may have negative pore pressures (that is, they may be in a state of suction), which may cause an apparent cohesion which is dissipated upon wetting (Sowers and Richardson, 1983).

We believe that the long-term stability of slopes of nonplastic saprolite and weathered rock can generally be safely evaluated using fully softened shear-strength parameters as the lower boundary of strength along an adversely oriented, extremely weathered or clay-filled joint, because drainage paths are adequate to permit drained shear. However, highly plastic saprolite containing clay-filled joints may not be adequately evaluated using this method; such a setting may be rather common on some mafic rock and on diabase. For most slopes in residuum and weathered sedimentary rocks of the Triassic Lowland, we believe that long-term stability can also be evaluated using the fully softened shear-strength parameters as a lower boundary, for the great majority of slopes, because of fractures that are commonly open. For clay-filled fractures and joints, however, lower strengths may be applicable.

In contrast to the rather brittle stress-strain properties of saprolite and residuum, colluvium in the Piedmont and Triassic Lowland commonly has approximately equal peak and residual shear strengths.

Potomac Formation sediments in many places are intensely softened and fractured by weathering near the ground surface and along the unconformable contact with overlying deposits. Also, unweathered sand, silt, and clay of the Potomac Formation typically have a stiff to hard consistency, and at many places are too strong to be sampled with conventional Shelby tubes. However, beneath and intersecting these strong soils, thin, weak zones, typically $0.25 \mathrm{~cm}$ thick, may be present at various orientations. They are rather common in clay and silt, may be subhorizontal and continuous for long distances, and are irregularly spaced. They are rarely present in sand of the Potomac Formation. These weak zones commonly have a soft to medium consistency. Detection of the zones is difficult, yet they can be critically important to short- and long-term slope stability. These zones probably have multiple origins related to swelling forces and tectonic activity (Langer and Obermeier, 1978).

\section{COMPRESSIBILITY TEST METHODS AND CHARACTERISTICS OF UNITS}

Techniques commonly used by engineering consultants to evaluate compressibility characteristics in the study area include consolidometer, SPT, pressuremeter, and cone penetrometer testing. Conventional soilmechanics methods using a consolidometer are most commonly used by consultants to estimate settlement of structures in the nonconsolidated materials described in table 1. Geologic materials in which large settlements can take place include: colluvium; alluvium, especially where organic; the upper 2-7 m of the Potomac Formation where surface weathering or landsliding has weakened or remolded the soils; weak zones and ancient landslides in the Potomac Formation (which may be buried beneath younger sediments); weak saprolite and residuum; and tectonically sheared zones and faults in bedrock.

Control of settlement is almost always the governing criterion for dimensioning linear footings and spread footings on saprolite and residuum. Because of the presence of multiple quartz bodies and hard masses of other materials, it is often difficult to obtain representative samples for testing to calculate settlement in the gneiss, schist, and metagraywacke unit, in the phyllite unit, and to a lesser extent in the granitoid rock unit. To avoid this sampling problem, many consultants use SPT blow-count data for design of columns having loads of as much as about $45,000 \mathrm{kgf}$. Numerous correlations between SPT data and column design loads have been prepared, and figure 19 shows the range commonly used. The correlations are based on an allowable maximum settlement of $2.5 \mathrm{~cm}$, with the assumption that: the ground-water table is beneath the footing a depth of at least one or two times the width of the footing, there is no interaction between footings, and the footing is not underlain by softer material. The higher loads are permitted for coarser grained saprolite, such as that generally found in the granitoid rock unit or at the base of the weathering profile of the saprolite zone. Similar relations are used for design of footings on residuum of the Triassic Lowland. Where high quality samples can be obtained and tested in the laboratory, design values commonly exceed those in figure 18. A difficulty with using the SPT blow counts is that quartz veins commonly affect the data, making them unrealistically high. Personal judgment has been about the only way to eliminate unrepresentative data. 


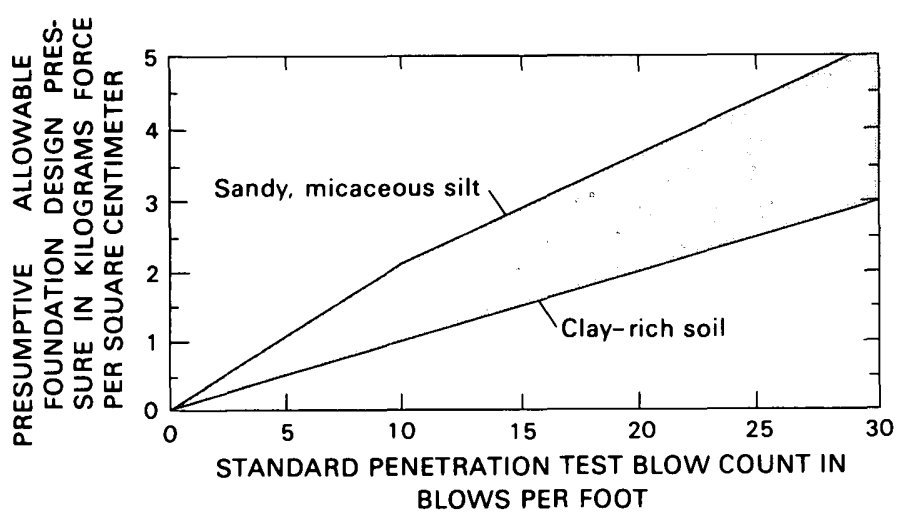

FIGURE 18.-Relation of allowable foundation pressure on saprolite or residuum to Standard Penetration Test blow count for column loads of $12,500-45,000 \mathrm{kgf}$. Where ground-water table is deep, there is no interaction between footings, allowable total settlement is as much as $2.5 \mathrm{~cm}$, and blow counts remain constant or increase with depth. Data for Fairfax County and vicinity.

A conventional consolidometer analysis can be used to estimate foundation settlements on low-density residuum, saprolite, and unstructured saprolite (soil in which jointing, fracturing, and fabric of what was originally saprolite has been obliterated), where relatively undisturbed thin-walled tube samples can be taken. However, it is generally not possible to obtain high-quality samples in materials having SPT blow counts exceeding 10-15 (Martin, 1977) and in saprolite containing rock fragments.

Thus, consolidation testing is impractical for most residual soils unless undisturbed block samples can be obtained using sampling equipment having largediameter shafts. The expense of this type of sampling is beyond the means of most engineering projects. Another approach has been to utilize a plate-load test, an in-place test well suited to homogeneous residual soils, but the residual soils in the study area are commonly too variable to be analyzed by this test. Extrapolation of small plate-load-test settlement data for estimation of footing settlements in saprolite is also more difficult than in Coastal Plain soils. Full-scale load tests of prototype footings are generally too costly.

To resolve the consolidation testing problem, and other problems, devices have been used recently that obtain information needed for engineering design by means of field-test methods, such as the cone penetrometer and the Menard pressuremeter (Martin, 1977). Advantages of the cone penetrometer are ease and economy of collecting closely spaced data and the ability to eliminate many unrepresentative readings caused by quartz veins and other thin, hard zones. Weak zones critical to design can be accurately located and later sampled for laboratory testing. The pressuremeter also eliminates most effects of thin, hard zones and quartz veins, and typically shows much less data scatter than SPT blow counts. The pressuremeter has been used primarily for testing weathered, weakly foliated rocks or highly foliated rocks having steep dips, conditions which generally prevail in the study area. We believe that the pressuremeter is useful for conservatively estimating settlements in these geologic settings, because estimates based on the horizontal compressive strains should equal or exceed the actual vertical compressive strains. This opinion is based primarily on consolidometer data showing that, for a given stress, straining perpendicular to foliation commonly exceeds straining parallel to foliation. The loading for a typical foundation in the study area is parallel to the foliation. Pressuremeter data for highly foliated rocks having lowangle dips may thus underestimate settlements, but such geologic conditions are rare in the study area.

Consolidometer data on saprolite near the ground surface typically show a very poorly defined apparent preconsolidation stress, slightly greater to much greater than existing overburden load, based on the Casagrande construction method for estimating preconsolidation stress (Leonards, 1962). With increasing depth, the preconsolidation stress tends to increase, but locally, values may be much lower. This apparent preconsolidation stress is almost invariably the result of incomplete disintegration of the bedrock, rather than an indication of past loading. Very weak saprolite is highly susceptible to disturbance during sampling, and consolidometer data on samples taken with thin-walled tubes may have unrealistically low apparent preconsolidation stresses. These low stresses can cause building settlements to be greatly overestimated.

Some saprolite may have properties conducive to large amounts of long-term settlement, and inclusion of secondary compression in settlement calculations should be made for many structures. Highly micaceous saprolite is thought to be especially prone to long-term settling (Sowers, 1963; Sowers and Richardson, 1983).

Exposed saprolite can swell and weaken very quickly (see the section on "Excavation properties"), which can cause foundation settling to greatly exceed predictions which were carefully made on saprolite which has not swollen. The rate of weakening is illustrated by the following incident, which took place in the Piedmont, near Fairfax County. A 10-m-deep excavation was made in saprolite and left open for about 2 yrs. The base of the excavation was in saprolite which testing showed had SPT blow counts of approximately 100 per foot. When construction was begun after the 2-yr hiatus, an additional $10 \mathrm{~m}$ had to be excavated to reach saprolite having STP blow counts of 100 per foot. The reasons for such rapid changes in saprolite properties are not 
known, but they may be due to the presence of high lateral stresses (and possibly a high mica content or tectonic stresses), or to mineralogical changes. Because reasons for the changes are not known, deep excavations exposed for a long time should be reevaluated.

Estimates of settlement under loads less than the apparent preconsolidation stress are commonly calculated by conventional methods based on the rebound during unloading of consolidometer samples. Settlement can be large, even under loads less than the apparent preconsolidation load. Throughout the county, the coefficient of compression (the change in void ratio per logarithmic cycle) during unloading typically varies from 0.03 to 0.06 for the most intensely decomposed saprolite, and during loading commonly ranges from 0.2 to 0.4 . Very high coefficients may occur even in soils classified as SM (table 6). Void ratios as large as 0.80 are common in the most intensely weathered saprolite.

Saprolite beneath Coastal Plain sediments commonly has higher compressibility and lower shear strength than the overlying sediments. Here the buried saprolite varies from 3 to $7 \mathrm{~m}$ in thickness at many places, but may be much thicker, especially beneath the sediments west of the Fall Line. At some places saprolite beneath Coastal Plain deposits has clay-coated joints, which have effective peak friction values as low as $10^{\circ}$ and no apparent cohesion on the strength envelope. Apparently the clay has washed down from the overlying sediments.

\section{ALLOWABLE BEARING PRESSURE}

The allowable bearing pressures shown in tables 1-4 apply to conventional-size footings, mats, caissons, or piers which have a bearing area of at least $1 \mathrm{~m}$. Minimum values shown in the tables are generally for locations where the ground-water table is near the base of the foundation. The bearing-pressure values in the tables are for undisturbed soils from which water is excluded and which have not been remolded by excavation equipment. Where a range of bearing pressures is given in the tables for a unit, the appropriate values must be obtained from test data at specific locations. The tabulated values do not include the effects of surcharge surrounding the bearing level of the foundation, or interaction between footings. For deeply buried footings, piers, or caissons in cohesionless strata, conventional analyses may increase these values if settlements for increased loads are tolerable. Alternatively, bearing pressures for small footings or blocks for support of temporary bracing placed at or near the surface of cohesionless materials must be decreased using data from conventional analyses which account for the smaller footing widths.

Footings for houses and other light structures which are $0.8 \mathrm{~m}$ or more below finished exterior grade are normally deep enough to prevent frost heaving and large differential settlements. Light structures are normally founded on wall footings at least $0.4 \mathrm{~m}$ wide and column footings at least $0.6 \mathrm{~m}$ by $0.6 \mathrm{~m}$ in plan view.

Specific types of piles used in each unit, because of geologic characteristics and strength or compressibility of the materials, are noted in the tables. $\mathrm{H}$ piles are commonly used in soils containing boulders, for bridge foundations on saprolite, or in residuum where many hard zones require a penetration-type pile. Displacement piles are used in very weak saprolite or residuum or in weak sediments, in some places. Pressure-injected footings are used in many places where soft material is underlain by fairly firm material within $10-15 \mathrm{~m}$ of the base of the building.

Notes about the use of caissons are not included in the tables, but some criteria for their use are discussed below. Caissons are commonly used throughout the study area to found heavy structures on very strong, relatively incompressible materials. Materials having these properties are unweathered Potomac Formation sediments, very strong saprolite, and weathered and unweathered rocks of the Piedmont. Strong residuum on the Triassic Lowland sedimentary rocks can also be used to found caissons. The residuum is so thin that it is generally more economical to place caissons in weathered or unweathered rock, except in the conglomerate unit, where the residuum is thick at many places. Instability of the soil around the bell-shaped excavation at the base of caissons is sometimes a problem in the Potomac Formation. Large chunks of soil from adversely oriented joints and shear zones may fall into the excavation.

The minimum SPT blow-count value for using caissons in saprolite and residuum is about 100 blows per 6-8 in.; bearing pressures for material having these blow counts range from about 5 to $10 \mathrm{kgf} / \mathrm{cm}^{2}$. If the base of the caisson is below the ground-water table, the caisson must be emplaced as soon as possible after excavation to prevent softening of the soil at its base. Saprolite must be carefully inspected to a depth at least equal to the diameter of the bell excavation (generally $1.7-2.7 \mathrm{~m}$ ) to ensure that there are no sheared or weak zones. Allowable loads increase as the degree of weathering of material decreases, and allowable bearing pressures on unweathered rock range from about 15 to $60 \mathrm{kgf} / \mathrm{cm}^{2}$, depending on joint spacing and orientation.

Physical properties of weathered bedrock which are normally critical to design of caissons can be estimated from SPT blow-count data. Compressibility of the mass is almost always the governing factor for design of footings in saprolite and residuum having blow-count values less than about 60 per foot. Closure of joints is normally the most important design factor for materials 
having higher blow-count values, but the shear strength of the mass or along joints can also be critical, especially for material having blow-count values. of about 60 per foot. Part of the geologic reason for this change of governing design factors is that joints in the weaker saprolite are commonly cemented and filled by oxides or dense clay; joint fillings are greatly diminished and cementation strengths are commonly much lower near the base of the saprolite zone and at greater depths.

Saprolite having low SPT blow-count values is very deep at some places, and founding buildings on caissons is impractical or very expensive (material having blowcount values of 10 or less may be $25 \mathrm{~m}$ or more deep at some places). In such deep, weak saprolite, other design options for large buildings include a mat foundation or a displacement-pile system.

Displacement piles, including pipe piles and steptapered piles, have been used successfully to support large buildings in the study area, but are generally planned cautiously by designers because of pile-driving problems. Where the weathering profile is erratic, displacement piles may be impossible to drive through a thin, hard, less weathered zone to deeper, stronger material. These piles are most suitable for a uniformly weathered soil profile, where pile penetration is unobstructed and skin friction is developed. Augered grouted piles can be used to penetrate hard zones in saprolite but have less skin friction than other types.

Pressure-injected footings are commonly used where weak saprolite or residuum at the ground surface is underlain by firmer material (having SPT blow-count values exceeding 30 per foot) within 10-15 $\mathrm{m}$ of the base of the structure, but the material is not strong enough to support caissons. These footings are also commonly used in lowland areas, where fine-grained, weak sediments are underlain by much stronger materials such as coarse-grained sediments, the Potomac Formation, or weathered rock. Pressure-injected footings are normally installed by (1) driving a hollow-pipe pile into the ground, removing the soil from the inside of the pile, and forcing concrete into the ground as the pile is withdrawn, or (2) augering a hole into the ground and then placing concrete in the hole.

TABLE 8.-Types of deep foundations and loads commonly supported by them

\begin{tabular}{|c|c|}
\hline Foundation & Common load/unit (kgf) \\
\hline $\begin{array}{l}\text { Caisson } \\
\text { Pressure-injected footing } \\
\text { Step-tapered concrete pile } \\
\text { Driven pile } \\
\text { Augered grouted pile }\end{array}$ & $\begin{array}{r}180,000 \\
90,000 \\
70,000 \\
45,000 \\
35,000\end{array}$ \\
\hline
\end{tabular}

TABLE 9.-Typical foundation-pile loads on stronger materials

\begin{tabular}{lr}
\hline Material & Load (kgf) \\
\hline Upland gravel unit compact sands (where not & \\
underlain by fine-grained soils or weathered & \\
materials of the Potomac Formation) $-\cdots$ & $45,000-60,000$ \\
Unweathered Potomac Formation - & $55,000-70,000$ \\
Strong saprolite - & \\
Unweathered rock $-0,000-80,000$ \\
\hline
\end{tabular}

Table 8 shows loads commonly placed on various types of deep-foundation systems.

Some units characteristically support higher loads on deep-foundation systems than others, and these units are commonly sought by foundation designers. Some typical ranges of loads on a single foundation pile in the stronger materials, as limited by the strength of the bearing material, are shown in table 9 .

\section{SLOPE STABILITY}

Both natural-slope stability and long- and short-term (construction period) stability of cut slopes are discussed in this section of tables 1-4. "Utility excavations" are near-vertical, short-term cuts; "long slopes" are permanent slopes higher than about $5 \mathrm{~m}$ which slope less than about $60^{\circ}$. More detailed discussions of the relationship of the geologic setting to different types of slope-stability problems throughout the study area are in Langer and Obermeier (1978) and Obermeier (1979).

Conventional soil-mechanics methods for exploration and design are adequate for most soils listed in table 1 (nonconsolidated materials). However, the alluvium and upland gravel units and the Potomac Formation sands contain iron oxide-cemented layers and boulders that cannot be easily penetrated; such layers and boulders are common. Also, all types of Potomac Formation sediments may be too hard to sample using conventional steel Shelby tubes and may require use of residual shear-strength parameters for permanent slope design.

Naturally occurring and construction-related landslides in Potomac Formation clay and silt are normally not large, averaging about $30-50 \mathrm{~m}$ across the slope and $25 \mathrm{~m}$ downslope. However, the slides are widespread and commonplace, and have caused much destruction and damage. Slumping due to swelling and weakening of clay commonly occurs on slopes as low as $10^{\circ}$ as long as 5-10 yrs after excavation. The slumps normally occur after intense rain or in the spring when melted snow and prolonged rainfall saturate the ground. Design of permanent slopes in these materials is complicated and 


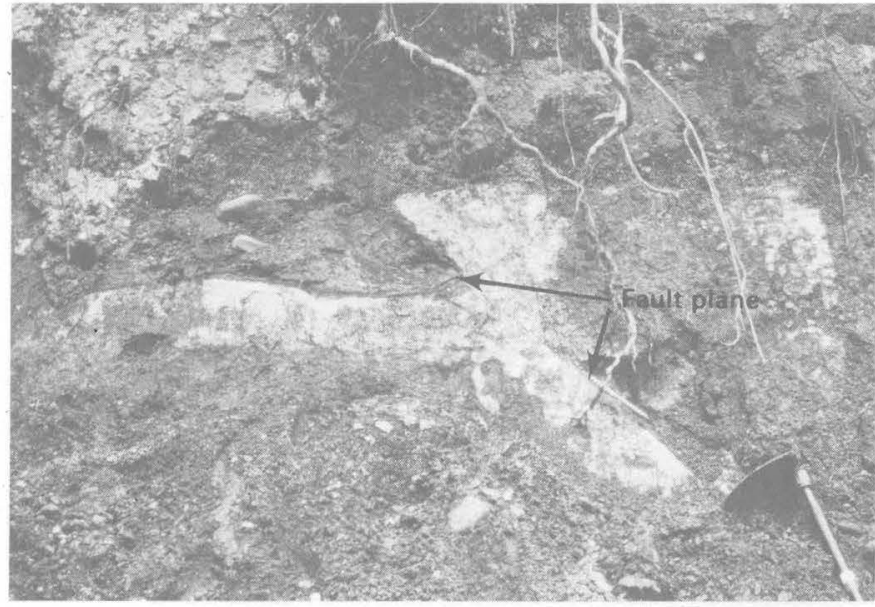

Figure 19.-Thrust fault in Potomac Formation silt and clay, Fairfax County and vicinity, Virginia. Displacement is about $25 \mathrm{~cm}$. rather uncertain unless extremely conservative design parameters are used. Factors causing these slides include: near-surface softening and fracturing; softening along the contact with the upland gravel unit or with the colluvium and lag gravel units; joints and tectonically related shear zones in otherwise stiff to hard deposits (fig. 19); water in joints; perched water zones; and concentrated water flow at the contact between the upland gravel unit and the underlying Potomac Formation sediments. The relationship of these different zones of weakness to the geologic setting is shown in figure 20 .

Both previously failed and unfailed slopes on highly fractured Potomac Formation clay should be designed using residual (drained) shear-strength parameters and should allow for the presence of a shallow ground-water table, even though many first-time (initial) landslides probably take place by undrained or partly drained shear through subhorizontal joints and partings (fig. 21).

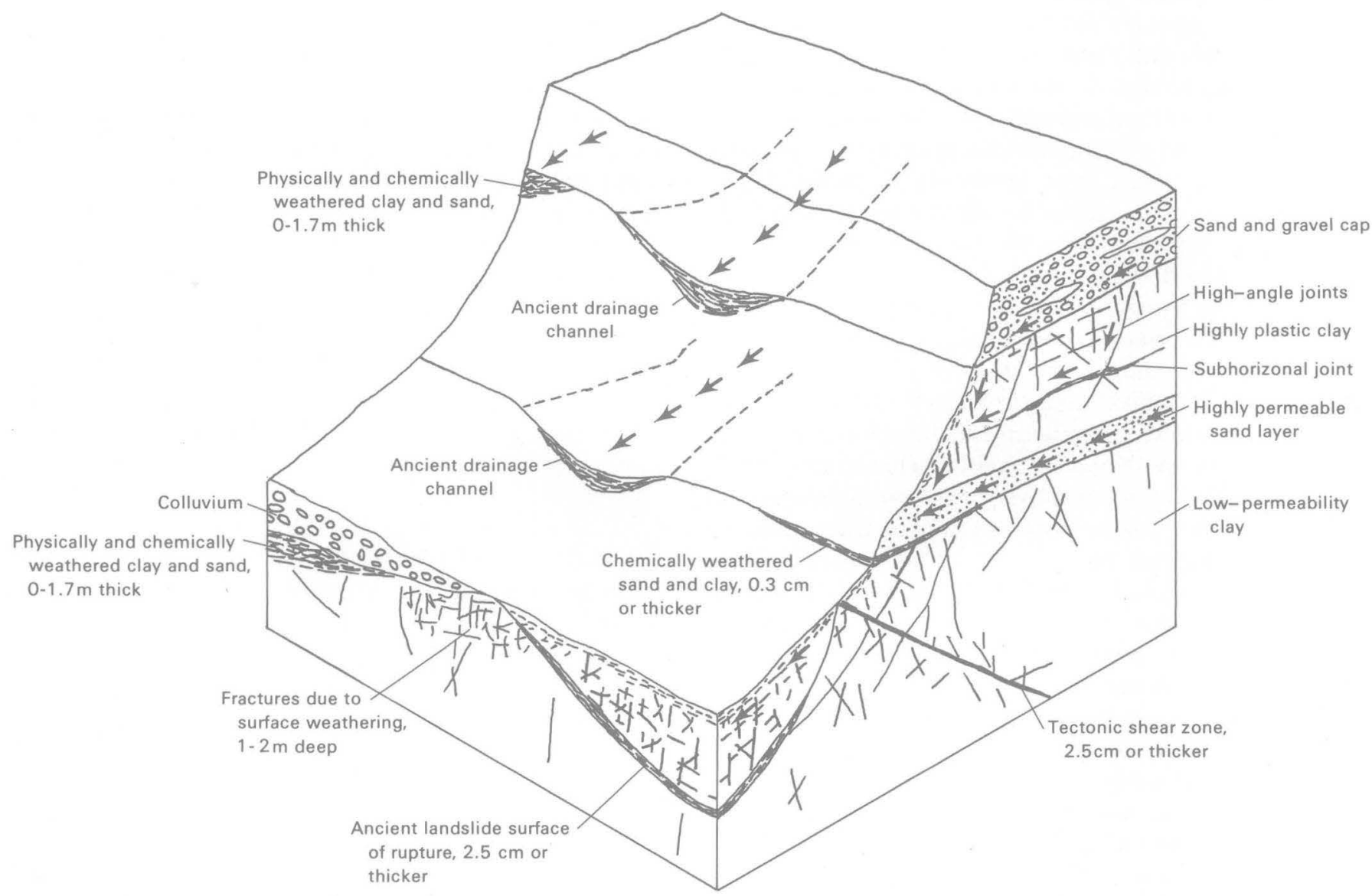

FIGURE 20.-Diagrammatic representation of critical zones of weakness in slopes on the Potomac Formation, Fairfax County and vicinity, Virginia. Arrows show areas of concentrated water flow. 


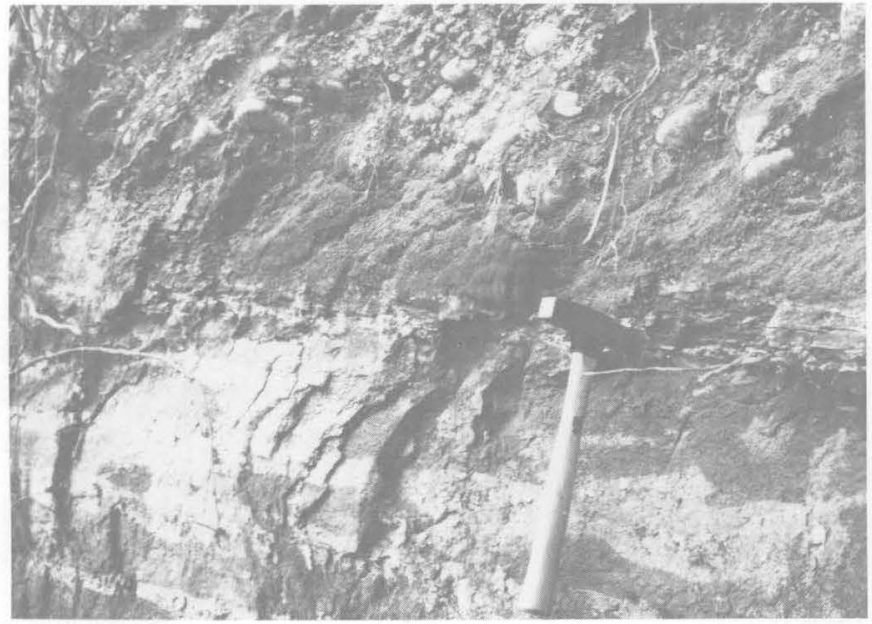

Figure 21.-Zone of closely spaced subhorizontal partings (at head of hammer) through Potomac Formation clay, Fairfax County and vicinity, Virginia.

The clay along the breaks is commonly weathered and severely softened as much as $0.5 \mathrm{~cm}$. The breaks may also be filled with clay, which has been transported by circulating water. Slopes on silt containing little clay and on clay-bearing sand can be safely designed using normally consolidated drained peak shear-strength parameters measured on remolded samples (that is, the fully softened strength). Selection of realistic parameters for slightly to moderately plastic clay is often controversial; values between residual and fully softened shear-strength parameters are normally used. Because of the difficulty of ensuring that all weak or water-bearing zones have been found during exploration, quite conservative values are generally appropriate. All slopes which have previously failed should be designed using residual shear-strength parameters from the preexisting surface of rupture. The most practical solutions for stabilization are normally dewatering, flattening of slopes, or removal of the slump debris, though a wall or buttress may be preferable for short, steep slopes.

Near-vertical relict joints so widespread in Potomac Formation clay and silt can make cuts unstable during the construction period (fig. 22). Withington (1964) reported that a vertical face collapsed and killed workers shortly after excavation; the collapse possibly was caused by excessive water pressure in joints.

Naturally occurring landslides (slumps) are very rare in Piedmont colluvium, but excavations causing small changes in natural slope angles can make slopes unstable. Landslides in Piedmont colluvium are generally related to water pressure in the underlying jointed bedrock, and they can generally be stabilized most economically by draining the jointed rock.
Although slides are rare in Piedmont colluvium, active creep is indicated by trees bowed at their bases on slopes greater than about $17^{\circ}$ (30 percent). Apparently the colluvium does not move on natural slopes at depths greater than about $1-1.3 \mathrm{~m}$, but near-surface movement can damage walls extensively.

Natural and cut slopes in saprolite and weathered rock are commonly stable on much steeper slopes than in colluvium, because colluvium apparently has been weakened to the residual shear-strength condition. Cut slopes of $27^{\circ}$ (50 percent) or less on saprolite and stronger rock usually do not fail, and these materials are usually stable at much higher angles. However, moderately to highly plastic saprolite on mafic and ultramafic rocks commonly fails on long slopes of less than $27^{\circ}$, as does saprolite containing joints coated with weak, soft clay, which is present beneath some Coastal Plain deposits, especially east of the Fall Line.

Long, unbuttressed slopes in saprolite and weathered rock at angles greater than $25^{\circ}-30^{\circ}$ most commonly fail along shear zones. Because shear zones commonly parallel foliation, surface observations of foliation dip and strike can be used to locate the most probable critical surfaces. Long-slope failures take place along joints to a much lesser extent. Joint orientation, continuity, spacing, and offsetting are critical to stability. The largest landslides usually occur where the shear surface is parallel to foliation. Slides which shear through joints not parallel to foliation are commonly much smaller but can still be large enough to cause major construction problems.

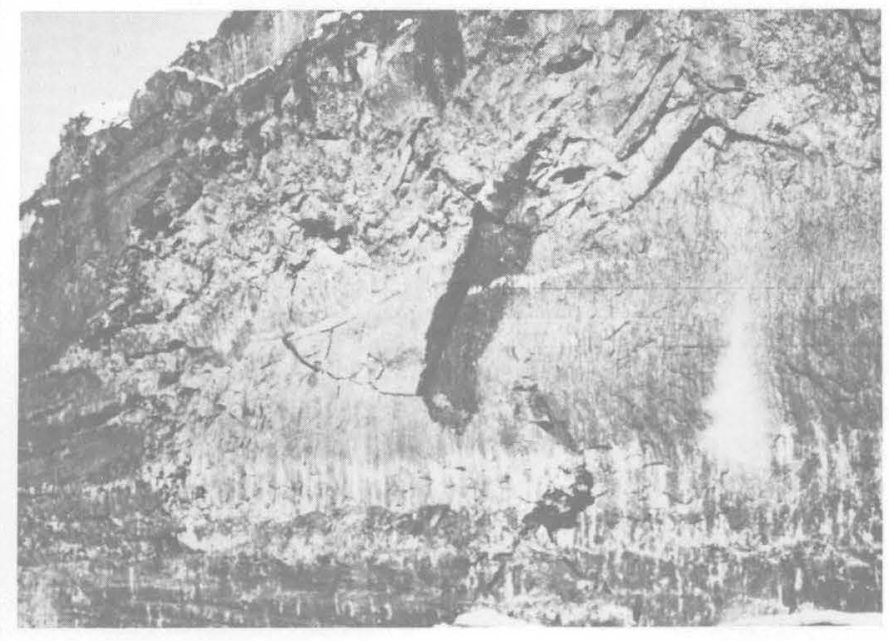

FIGURE 22.-Failure of the wall of an excavation exposed a nearvertical joint surface (right half of photograph) in Potomac Formation clay and silt. Exposure is about $5 \mathrm{~m}$ high. Near Fairfax County, Virginia. 


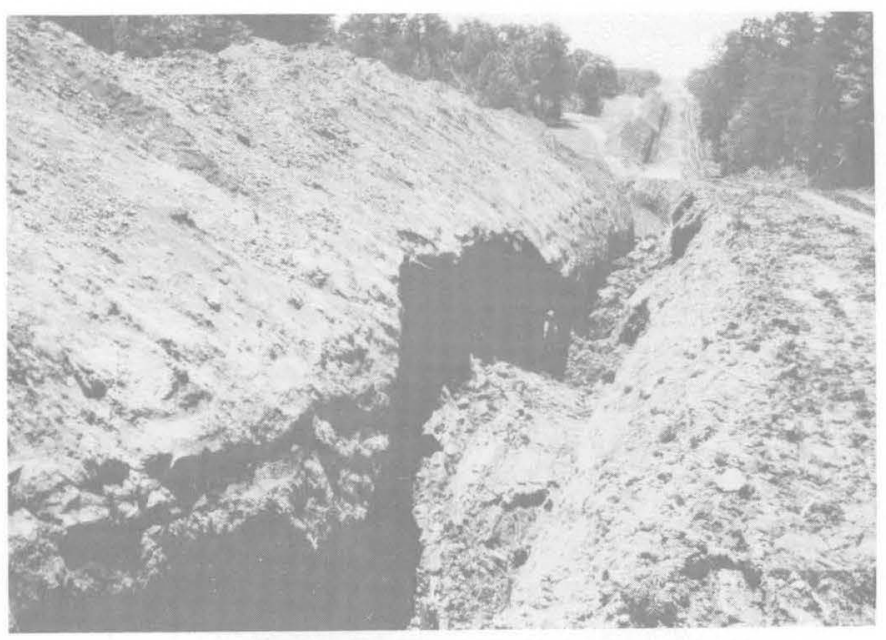

Figure 23.-Wall failures in pipeline excavation in saprolite, Fairfax County and vicinity, Virginia.

Cut slopes in Triassic Lowland rocks behave in a manner generally similar to that of Piedmont materials. However, in the Triassic Lowland, (1) adversely oriented, continuous joints or partings are less common; and (2) rapid weathering of some siltstone undermines stronger, more resistant sandstone. Slopes of $25^{\circ}-30^{\circ}$ or less should be considered for permanent stability on sandstone interbedded with siltstone which weathers and softens rapidly.

Short-term stability of trenches excavated in Piedmont saprolite or weathered rock and in Triassic Lowland residuum or weathered rock normally depends primarily on the presence or absence of adversely oriented, poorly cemented, or slickensided joints, partings, or shear zones. Trench walls commonly fail through these weak zones, especially when the trenches have been open a short time (fig. 23). Walls in saprolite most commonly fail where the trench parallels steeply dipping foliation. Ground water can greatly aggravate instability problems. Micaceous saprolite sloughs very easily and can even ravel through braced excavations, so they should be inspected after rainy periods.

Throughout the study area, all geologic materials older than the upland gravel unit and all weathered products (such as saprolite or residuum) have joints and fractures at unpredictable orientations and spacings, and these weak zones may cause sudden collapse of trenches deeper than about $1.5 \mathrm{~m}$. These weak zones are impossible or impractical to locate during exploration, and standard soil-mechanics classification and index tests cannot be used to predict wall stability. Unsupported excavations in these materials may collapse any time, especially after rainy periods, endangering workers. Consequently, adequate shoring should always be used.

\section{ROAD-PERFORMANCE CHARACTERISTICS}

The influence of water on pavement performance, influence of water on laboratory test data, use of techniques for subbase stabilization, and factors causing distortion of roadways are discussed in this section of tables 1-4.

The highly plastic clay of the Potomac Formation can swell and weaken significantly, especially where exposed to concentrated water flow. Sewer lines and improperly filled trenches commonly cause distressed pavements, misaligned curbs, and rough roads. Highly plastic clay developed on bedrock of the Piedmont and Triassic Lowland can also cause these problems, but the clay generally does not fail as readily as Potomac Formation clay.

Lime can eliminate swelling of clay (especially clay over diabase); 5-7 percent lime (weight measure) mixed with the soil stabilizes it, but mixing the lime with clay that is too wet or dry is difficult. Addition of lime changes the clay to a soil that has either very low plasticity or none, and a plasticity index of less than 5 . Lime treatment also makes the soil friable, so that field compaction is much easier than for the plastic clays. These friable materials can be very susceptible to frost heaving or frost softening, however, and require cement stabilization according to specifications discussed below.

The micaceous silt so common in the Piedmont is especially troublesome under low- and medium-cost flexible pavements. Soils classified as A-4's and A-5's by the AASHTO (American Association of State Highway and Transportation Officials) classification system almost invariably have very low soaked CBR (California Bearing Ratio) values (Yoder, 1959), and are extremely susceptible to both frost heaving and frost softening. CBR values on samples of A-4 and A-5 soils compacted to Standard Proctor (Yoder, 1959) specifications commonly range from 15 to 25 on unsoaked samples, and from 3 to 5 on soaked samples. Frost softening is commonly so severe on roads having poor base drainage that pavements disintegrate completely under traffic loading during periods of thawing. About the only methods to protect pavements on these soils are to keep the road base dry by means of base-course drainage or to stabilize the soil with cement.

Use of CBR data from soaked tests and use of opengraded (and presumably highly permeable) base courses together is a highly empirical and sometimes unsatisfactory design approach for two reasons: (1) CBR soaked test data, even though commonly very low, may not realistically simulate the effects of frost on the soil, and the frost softening may be worse than the data indicate; and (2) base courses commonly constructed to drain pavements are inadequate for removal of water. Cement 
is sometimes used to stabilize the silty soils, because it eliminates the adverse effects of soaking, frost heaving, and frost softening. For roads having moderate traffic loads, stabilization using 10 percent cement (volume measure) generally strengthens the soil enough to withstand breakdown by wetting and frost action.

Pavement support problems occur in the Triassic Lowland where bedrock is close to the base of the pavement, and water is perched above the bedrock. The most serious problems are with pavements underlain by silty residuum, and include frost heaving and frost softening, and pumping of rigid pavements. Cement stabilization is sometimes difficult to achieve because of the difficulty of pulverizing the residuum and weathered rock into a fine-grained soil, which precludes thorough mixing of cement and soil. Weathered materials not easily pulverized can be overlain with stronger material to eliminate possible support problems.

Seeps in stratified soils having alternating permeable and impermeable layers or at the contact of relatively permeable soil above bedrock are responsible for widespread and severe damage to pavement, even on major highways. Standard base courses are commonly inadequate to remove seeping water, and pumping, subgrade weakening, and frost softening of the road base result. Properly locating and installing drainage systems during construction can eliminate many of these problems.

\section{SEISMIC-REFRACTION-VELOCITY DATA AND INTERPRETATIONS}

Typical seismic-refraction compression-wave-velocity data are not shown in tables $1-4$, because seismic profiles for many units are similar, and because data are unavailable for nonconsolidated materials. Compressionwave data collected by small seismographs can often be used to determine the depth of weathered products on crystalline and sedimentary rocks of the study area which can be dug and ripped. Velocity data and interpretations are from Steve Garrison, Kidde Consultants, Manassas, Va.

The compression-wave velocity depends in a general way on the intensity of weathering; the velocity increases in less intensely weathered rocks. A fairly small range of velocities (velocity zone) can usually be associated with the different weathered zones.

The number of velocity zones in Piedmont or Triassic Lowland rocks depends primarily on the depth of weathering; rocks having shallow weathered profiles commonly have two observable zones, and rocks having deeper profiles have three zones. For example, sandstone, shale, siltstone, hornfels, diabase, and massive ultramafic rocks typically have two zones, whereas conglomerate, granite, gneiss, and interlayered schist and metagraywacke have three.

Typical velocity profiles for rocks of the Piedmont and the Triassic Lowland are shown in table 10. Where velocities exceed $2,750 \mathrm{~m} / \mathrm{s}$ in Triassic Lowland rocks, the rocks are probably diabase or contactmetamorphosed hornfels.

In rocks having three velocity zones, the uppermost two are distinct and easily separable, but the separation between the second and third zones is poorly defined in some places.

Detection of large quartz bodies which are surrounded by much weaker material is a common problem in the Piedmont. The weaker material can generally be ripped or excavated, but large quartz bodies must be blasted. Excavation by blasting is costly, and the depth of easily ripped or excavated material can be critical to the design location of foundation depth of buildings having as many as several stories. Perched ground water above unweathered rock causes apparent seismic velocities to be too high, so seismic-refraction data are not reliable for evaluating ease of ripping or digging of materials, especially the sedimentary rocks of the Triassic Lowland. Data from borings should be used in conjunction with seismic data for reliable interpretations.

\section{DIGGING OF MATERIALS}

Materials producing seismic velocities between 750 and $1,200 \mathrm{~m} / \mathrm{s}$ can commonly be dug using a backhoe mounted on a tractor such as a John Deere 450. Lighter power equipment is adequate to dig materials having velocities less than $750 \mathrm{~m} / \mathrm{s}$. Also, materials such as residuum, saprolite, or weathered rock which can be augered with heavy-duty, power-driven equipment can easily be dug with a backhoe, whereas weathered rock that cannot be augered can only be chipped with a backhoe.

\section{RIPPING OF MATERIALS}

The ease of ripping varies greatly with size and power of construction equipment. Charts showing correlation with compression-wave velocity are in Caterpillar Tractor Company (1978). Rippability of sedimentary rocks of the Triassic Lowland and saprolite having widely spaced joints can generally be estimated by using the lower range of velocities in these charts; in highly foliated, steeply dipping crystalline rocks in the Piedmont, materials producing higher velocities, even values 
TABLE 10.-Typical compression-wave velocity profiles for rocks in Fairfax County and vicinity

$$
[>\text {, more than] }
$$

\begin{tabular}{|c|c|c|}
\hline Depth (m) & Material & Velocity $(\mathrm{m} / \mathrm{s})$ \\
\hline \multicolumn{3}{|c|}{ Sandstone, siltstone, or shale of the Triassic Lowland } \\
\hline $0-1.7$ & $\begin{array}{l}\text { Residuum and weathered rock which can } \\
\text { be augered }\end{array}$ & $385-485$ \\
\hline$>1.7$ & $\begin{array}{l}\text { Weathered rock which cannot be augered, } \\
\text { and unweathered rock. }\end{array}$ & $1,200-2,750$ \\
\hline \multicolumn{3}{|c|}{ Deeply weathered Piedmont rocks } \\
\hline $\begin{array}{l}0-5 \\
5-6 \\
>6\end{array}$ & $\begin{array}{l}\text { Agricultural soil and saprolite zone --- } \\
\text { Weathered rock zone } \\
\text { Unweathered rock zone }\end{array}$ & $\begin{array}{r}300-375 \\
525-750 \\
1,000-4,000\end{array}$ \\
\hline
\end{tabular}

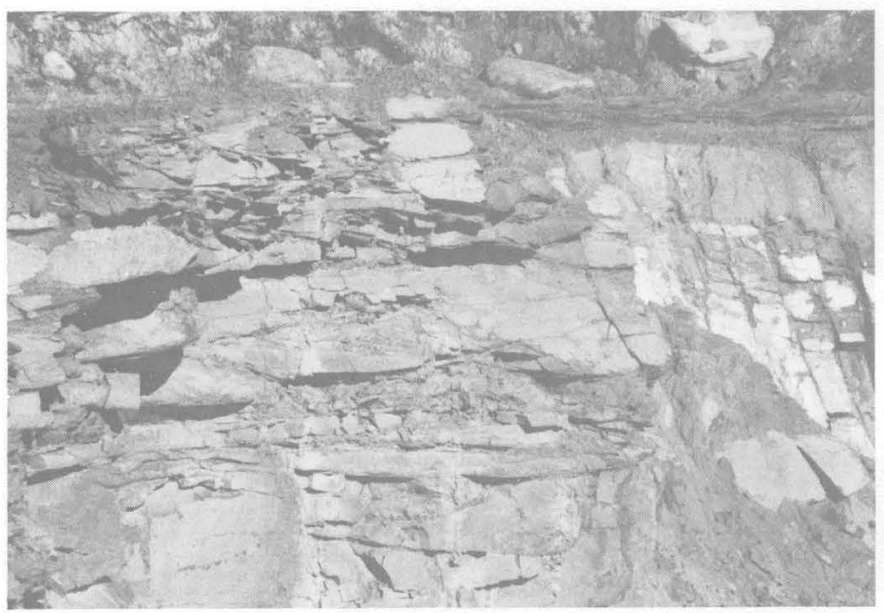

Figure 24.-Closely spaced subhorizontal joints in diabase, Fairfax County and vicinity, Virginia. Vertical part of outcrop is about $3 \mathrm{~m}$.

not shown on the charts, can be ripped. Rocks producing about $1,800 \mathrm{~m} / \mathrm{s}$ are the hardest which very heavy equipment (such as a Caterpillar D9 bulldozer with a ripper) can dependably rip weathered or fractured rock; this equipment can rip rocks having a velocity of as much as about $2,750 \mathrm{~m} / \mathrm{s}$, in some places. Rocks having higher velocities generally cannot be ripped and must be blasted.

The direction in which it is easiest to rip layered or foliated rocks can sometimes be determined by field seismic testing. Rocks are most easily ripped perpendicular to layering or foliation in the downdip direction, and dip direction sometimes can be determined by using a forward-and-reverse sequence of seismic profiles.

A predominant joint orientation can sometimes be determined by using a radial pattern of seismic lines. The lowest velocity is commonly perpendicular to the strike of joints, and the highest velocity is parallel to the strike of the joints.

\section{BLASTING OF MATERIALS}

Blasting is required to break some rocks producing seismic velocities as low as $1,850 \mathrm{~m} / \mathrm{s}$; blasting is needed to break almost all rocks having velocities greater than $2,700 \mathrm{~m} / \mathrm{s}$. Breaking rocks by blasting can be difficult in igneous rocks, especially diabase (fig. 24), which have sheeting joints parallel to the ground surface. These joints can absorb the blast energy, causing the rock to break into large blocks not easily handled or broken into smaller blocks.

\section{SELECTED REFERENCES}

American Society for Testing and Materials, 1978, 1978 Annual Book of ASTM Standards, Part 19: Philadelphia, Pa., American Society for Testing and Materials, $560 \mathrm{p}$.

Caterpillar Tractor Company, 1978, Handbook of ripping (6th ed.): Peoria, Ill., Caterpillar Tractor Company, publication AEDQ4007, 30 p.

Cleaves, E. T., 1974, Petrologic and chemical investigation of chemical weathering in mafic rocks, eastern Piedmont of Maryland: Maryland Geological Survey Report of Investigations 25, 28 p.

Deere, D. U., 1971, The foliation shear zone-an adverse engineering geologic feature of metamorphic rocks: Boston Society of Civil Engineering Journal, v. 60, no. 4, p. 163-170.

Deere, D. U., Hendron, A. J., Jr., Patton, F. D., and Cording, E. J., 1967, Design of surface and near-surface construction in rock, Chapter 1l, in Fairhurst, Charles, ed., Failure and breakage of rock: Symposium on Rock Mechanics, 8th, University of Minnesota, 1966, Proceedings; New York, American Institute of Mining, Metallurgical, and Petroleum Engineers, Inc., p. 237-302.

Deere, D. U., and Patton, F. D., 1971, Slope stability in residual soils: Panamerican Conference on Soil Mechanics and Foundation Engineering, 4th, San Juan, Puerto Rico, 1971, Proceedings, v. 1, p. $87-170$.

Drake, A. A., Jr., and Froelich, A. J., 1977, Preliminary bedrock map of Fairfax County, Virginia: U.S. Geological Survey Open-File Report 77-523, scale 1:48,000.

Drake, A. A., Jr., Nelson, A. E., Force, L. M., Froelich, A. J., and Lyttle, P. T., 1979, Preliminary geologic map of Fairfax County, Virginia: U.S. Geological Survey Open-File Report 79-398, scale $1: 48,000,2$ sheets.

Eggleton, R. E., 1975, Preliminary geologic map of the Herndon quadrangle, Virginia: U.S. Geological Survey Open-File Report 75-386, 8 p., 1 pl., scale $1: 24,000$.

Force, L. M., 1975, Preliminary geologic map of the Coastal Plain in Fairfax County, Virginia: U.S. Geological Survey Open-File Report $75-415,21$ p., 2 pls., scale 1:48,000.

Froelich, A. J., 1976, Surface materials map of the Vienna quadrangle, Virginia-Maryland: U.S. Geological Survey Open-File Report 76-533, 4 p., 1 pl., scale 1:24,000.

Froelich, A. J., and Heironimus, T. L., 1977a, Map showing contours on the base of saprolite, Fairfax County, Virginia: U.S. Geological Survey Open-File Report 77-710, scale 1:48,000.

1977b, Thickness of overburden map of Fairfax County, Virginia: U.S. Geological Survey Open-File Report 77-797, scale 1:48,000.

John, B. T., Sowers, G. F., and Weaver, C. E., 1969, Slickensides in residual soils and their engineering significance: International Conference on Soil Mechanics and Foundation Engineering, 7th, Mexico City, Mexico, Proceedings, v. 2, p. 591-597. 
Johnston, P. M., 1964, Geology and ground-water resources of Washington, D.C., and vicinity, with a section on Chemical quality of the water, by D. E. Weaver and Leonard Siu: U.S. Geological Survey Water-Supply Paper 1776, 97 p.

Johnston, P. M., and Salotto, B. V., 1962, Geology and ground-water resources of the Fairfax quadrangle, Virginia: U.S. Geological Survey Water-Supply Paper 1539-L, $61 \mathrm{p}$.

Johnston, R. H., and Larson, J. D., 1979, Principal sources of ground water in Fairfax County, Virginia: U.S. Geological Survey OpenFile Report 79-211, 1 pl.

Langer, W. H., 1978, Surface materials map of Fairfax County, Virginia: U.S. Geological Survey Open-File Report 78-78, 9 p., 1 pl., scale $1: 48,000$.

Langer, W. H., and Obermeier, S. F., 1978, Relationship of landslides to fractures in Potomac Group deposits, Fairfax County, Virginia: U.S. Geological Survey Open-File Report 78-779, 37 p.

Leo, G. W., Pavich, M. J., and Obermeier, S. F., 1977, Mineralogical, chemical, and physical properties of the regolith overlying crystalline rocks, Fairfax County, Virginia-a preliminary report: U.S. Geological Survey Open-File Report 77-644, 14 p.

Leonards, G. A., 1962, Foundation engineering: New York, McGrawHill, $1136 \mathrm{p}$.

Martin, R. E., 1977, Estimating foundation settlements in residual soils: American Society of Civil Engineers Proceedings, Geotechnical Engineering Division Journal, v. 103, no. GT3, p. 197-212.

Meuser, Rutledge, Wentworth, and Johnston, General Soils Consultant, 1969, Preliminary subsurface investigation [for Washington, D.C., Metropolitan Area Rapid Transit] Adopted Regional System 1968, revised 1969: U.S. Department of Commerce, National Technical Information Service [Springfield, Va., 22161] Report PB 184-066 [145 p.].

1972, Design sections K006 and K007-Vienna route [Va.]-Subsurface investigation crossing structures along I-66 and general earthwork: U.S. Department of Commerce, National Technical Information Service [Springfield, Va., 22161] Report PB 215-519 [54 p.].

1973, Subsurface investigation, section K006, Vienna route, west Church Station [Va.]: U.S. Department of Commerce, National Technical Information Service [Springfield, Va., 22161] Report PB 223-710 [32 p.].

1975, Subsurface investigation, section K007, Vienna Route [Va.]: U.S. Department of Commerce, National Technical Information Service [Springfield, Va., 22161] Report PB 239-698 [153 p.].

Nelson, A. E., 1976, Preliminary geologic map of the Coastal Plain and Triassic Lowland of Fairfax County, Virginia: U.S. Geological Survey Open-File Report 76-312, 17 p., 1 pl., scale 1:48,000.

1976, Surface materials map of the Herndon quadrangle, Virginia: U.S. Geological Survey Open-File Report 76-712, 7 p., 1 pl., scale $1: 24,000$.
Nutter, L. J., and Otton, E. G., 1969, Ground-water occurrence in the Maryland Piedmont: Maryland Geological Survey Report of Investigations $10,54 \mathrm{p}$.

Obermeier, S. F., 1979, Slope stability map of Fairfax County, Virginia: U.S. Geological Survey Miscellaneous Field Studies Map MF. 1072, scale 1:48,000.

Porter, H. C., Derting, J. F., Elder, J. H., Henry, E. F., and Pendleton, R. F., 1963, Soil survey of Fairfax County, Virginia: Washington, D.C., U.S. Department of Agriculture, Soil Conservation Service Series 1955, no. 11, 103 p.

Reed, J. C., Jr., and Obermeier, S. F., 1982, The geology beneath Washington, D.C. - The foundations of a nation's capital: Geological Society of America Reviews in Engineering Geology, v. 5, p. 124.

Sowers, G. F., 1963, Engineering properties of residual soils derived from igneous and metamorphic rocks: Panamerican Conference on Soil Mechanics and Foundation Engineering, 2nd, Sao Paulo, Brazil, 1963, Proceedings, v. 1, p. 39-62.

Sowers, G. F., and Richardson, T. L., 1983, Residual soils of the Piedmont and Blue Ridge, in Special problems in residual soils and rock: National Research Council, Transportation Research Board, Transportation Research Record, 919, p. 10-16.

Terzaghi, Karl, and Peck, R. B., 1967, Soil mechanics in engineering practice (2d ed.): New York, John Wiley and Sons, 729 p.

U.S. Geological Survey, 1967, Engineering geology of the Northeast Corridor, Washington, D.C., to Boston, Massachusetts-Bedrock geology: U.S. Geological Survey Miscellaneous Geologic Investigations Map I-514-A, scale 1:250,000, 7 sheets.

1967, Engineering geology of the Northeast Corridor, Washington, D.C., to Boston, Massachusetts-Coastal Plain and surficial deposits: U.S. Geological Survey Miscellaneous Geologic Investigations Map I-514-B, scale 1:250,000, 8 sheets.

1967, Engineering geology of the Northeast Corridor, Washington, D.C., to Boston, Massachusetts-Earthquake epicenters, geothermal gradients, and excavations and borings: U.S. Geological Survey Miscellaneous Geologic Investigations Map I-514-C, scale 1:500,000, 2 sheets.

1970, The National Atlas of the U.S. Geological Survey: Washington, D.C., U.S. Government Printing Office, 417 p.

Wagner, A. A., 1957, The use of the Unified Soil Classification System by the [U.S.] Bureau of Reclamation: International Conference on Soil Mechanics and Foundation Engineering, 4th, London, 1957, Proceedings, v. 1, p. 125-134.

Withington, C. F., 1964, Joints in clay and their relation to the slope failure at Greenbelt, Maryland, December 28, 1962: U.S. Geological Survey open-file report, $7 \mathrm{p}$.

Yoder, E. J., 1959, Principals of pavement design: New York, John Wiley, 569 p. 